\title{
1 The Mediterranean in the European neighbourhoods
}

\subsection{OVERVIEW OF THE MEDITERRANEAN REGIONAL INTEGRATION WITH EUROPE}

\subsubsection{Europe's Only Neighbourhood whose Population is Rising}

In the ITAN project we define the 'neighbourhoods' roughly according to the European Neighbourhood Policy (ENP), but only roughly. The Mediterranean neighbourhood includes Morocco, Algeria, Tunisia, Libya, Egypt, Israel, the Occupied Palestinian Territory, Jordan, Lebanon and Syria, but also Turkey, although the latter is no longer within the official ENP list since the EU recognised it as an applicant country for membership in 2005.

With 285 million inhabitants (2011), the Mediterranean neighbour countries comprise by far the largest European neighbourhood in terms of population, and it will be more and more so owing to population declines in other neighbourhoods (including the Western Balkans and the eastern neighbourhood and Russia), where demographic decline hampers economic development. Another asset of the Mediterranean neighbourhood is its natural resources, namely energy. However, there are shortcomings too, for example, climate change is putting further stress on water supplies, and thus agriculture. The Mediterranean neighbour countries are developing along a poorly sustainable model, with damaged agricultural land, large-scale urban sprawl, poor collective transport and lack of affordability of renewable energy for countries suffering from public budget deficit. Cities (comprising 190 million inhabitants today) count at least an additional 4 million people every year, and the proportion of people living in urban areas will rise from $66 \%$ in 2010 to $75 \%$ in 2025 , yet public planning does not address this growth. Political transition will also take a long time, with conflicts and wars hampering progress. Last but not least, these countries face territorial and social disparities and a huge gender gap in the labour market (Beckouche, Besnard and Pecout 2016). In terms of living conditions, infrastructures, public services and social development, southern Morocco, southern Algeria and southern Egypt, not to speak of 
Gaza, Libya and now northern and eastern Syria, are much more worrisome than the general difference in development level between Europe and this neighbourhood as a whole.

\subsubsection{Transports and Energy Networks, a Key for Regional Integration}

Thanks to the ITAN project, we now have at our disposal a thorough cartography and network database of the transport network of the wider European region (EU + neighbourhoods), ca 2010. This provides:

- a comprehensive view of this wider region today and tomorrow given the role of the transport network in territorial development;

- new possibilities for researchers to integrate social, economic and environmental data into these wide network data, so as to compute indicators of connectivity, accessibility and other socio-economic potential at this wider scale;

- in-depth analyses at a sub-regional scale, since this database is compliant with the overall ITAN database at local scale, which allows specific treatments for any territory of the area;

- further cooperation between the European stakeholders and their neighbour counterparts, in particular in the field of energy and transport infrastructure with regard to the immense needs of the neighbour countries.

The maps provided here display two types of opposition. The first is about demographic density. The second is about the network density: all of the European territory is meshed, to various degrees but anyhow meshed, including Eastern Europe up to Moscow and including Turkey in its European territory up to central Anatolia. In the Arab neighbour countries, the network is much more limited, for geo-climatic as well as economic reasons.

The road network in the neighbourhoods is less dense than in the EU. This is especially true for most remote Russian regions and for the desert areas in North Africa and the Eastern Mediterranean. The rail network shows an even sharper contrast between the North and South Mediterranean regions, and is sparser than the road network and of poor quality. Similarly to the road network, the density decreases when moving away from the EU, with a very limited network in the Maghreb, the Eastern Mediterranean and Turkey. The railway issue is of utmost importance for inter-city connection, for two reasons. The first is environmental: collective transport and especially rail transport favour high urban density instead of urban sprawl. The second reason is economic: high urban density and good 


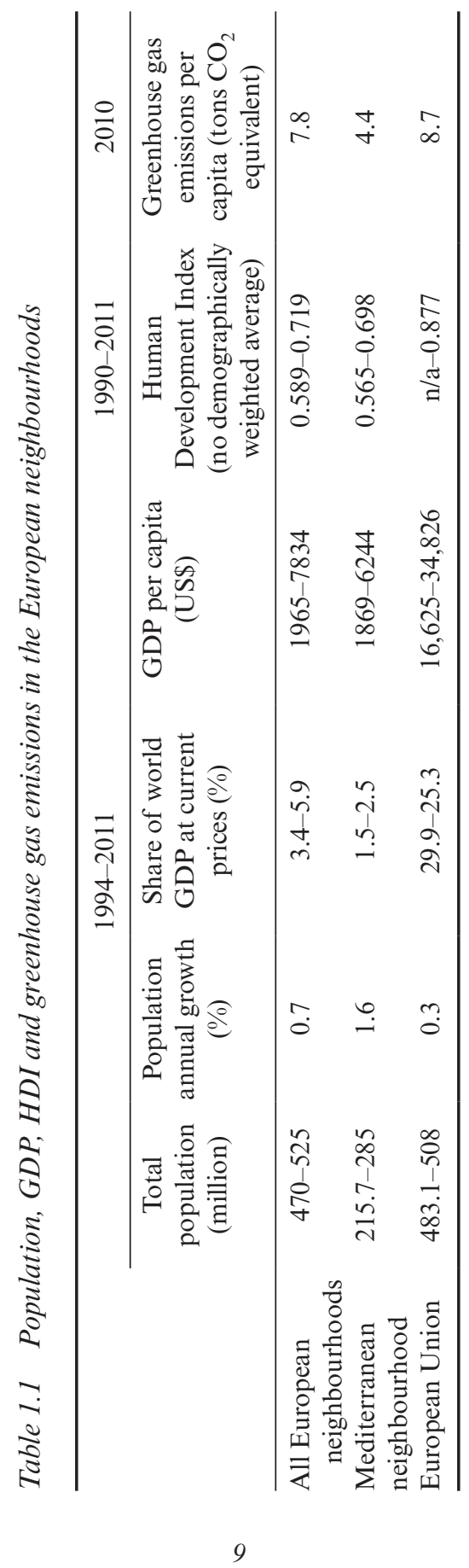




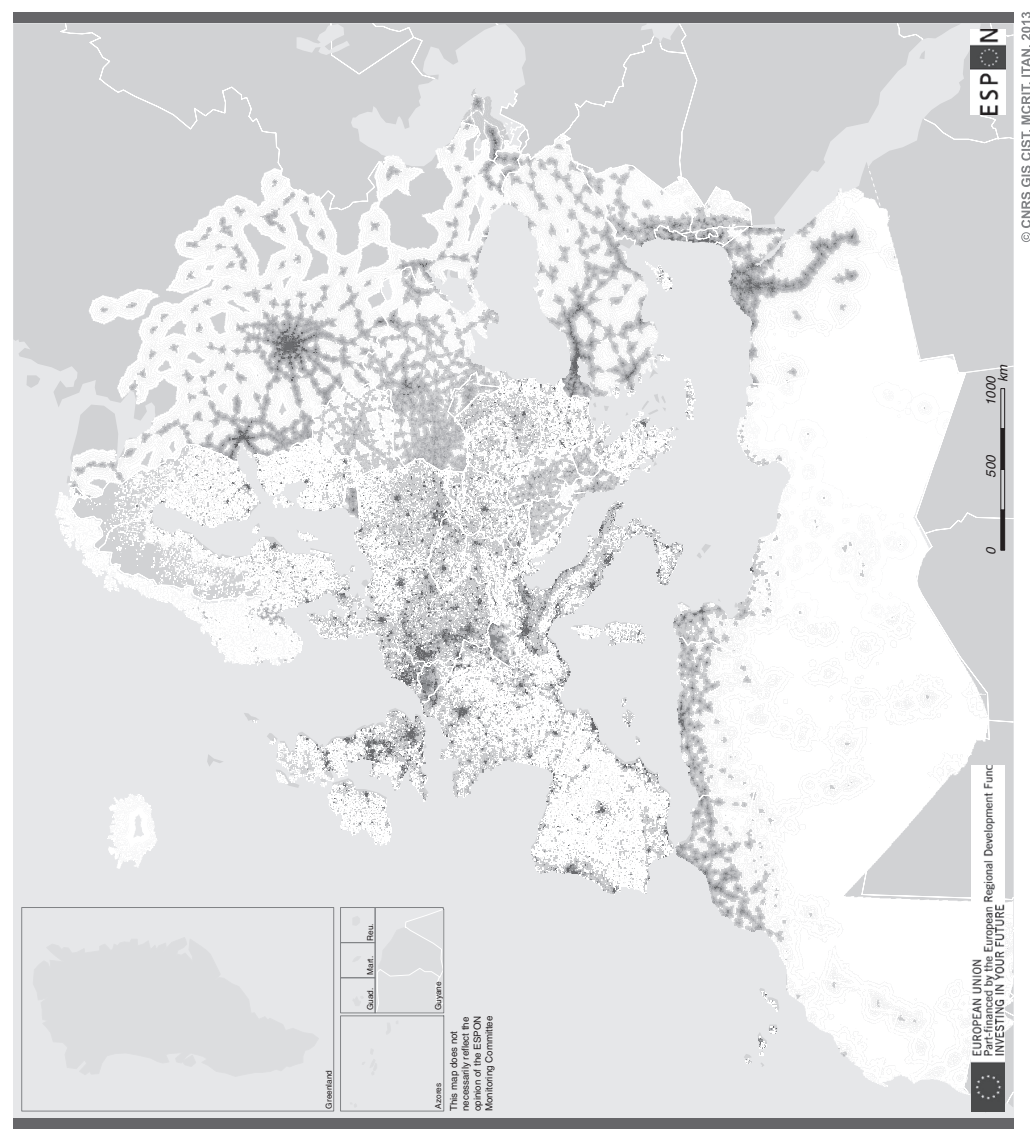

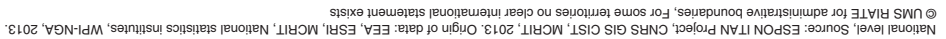




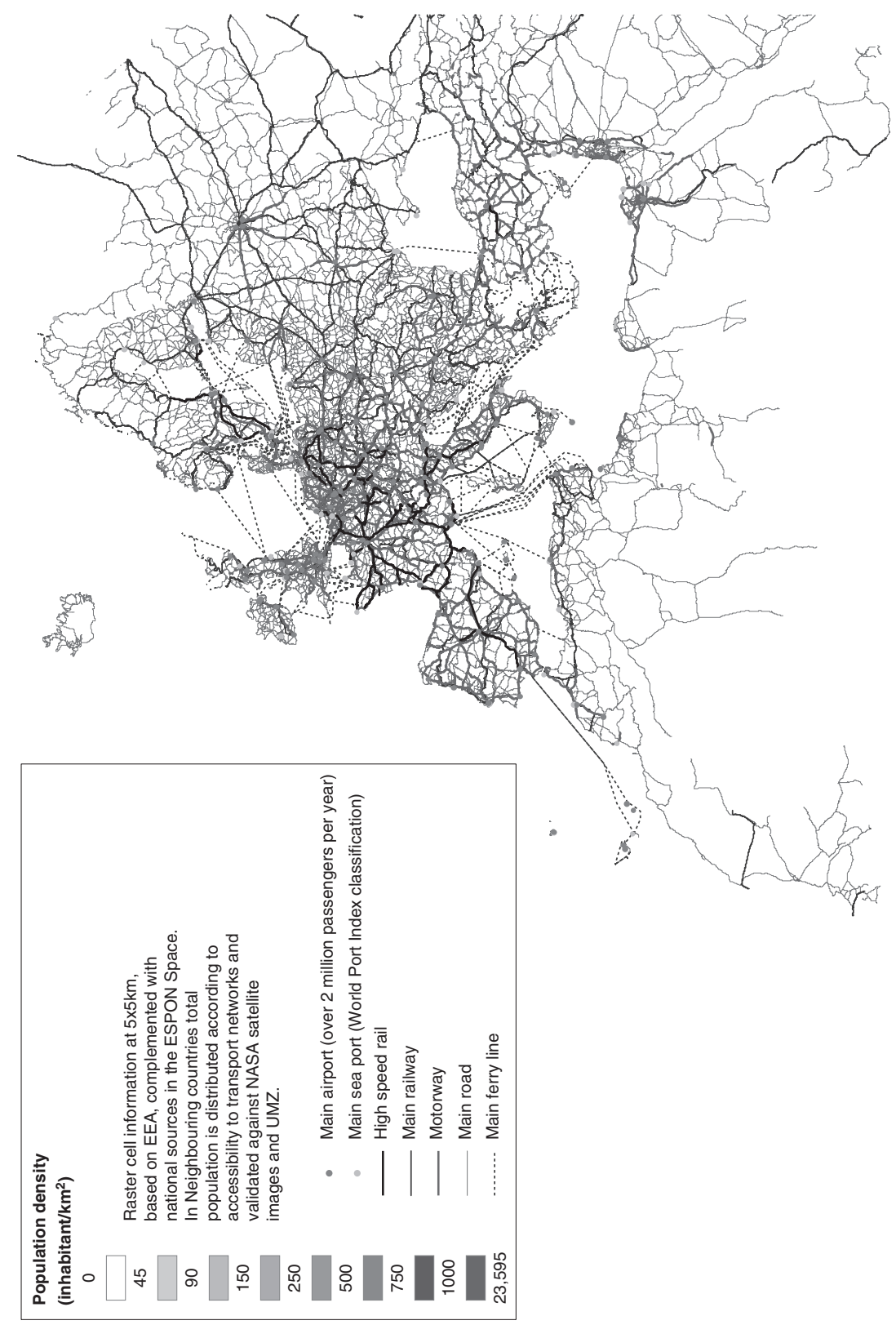

$\stackrel{ }{2}$

5
5
0
$\vdots$
5
$\vdots$
$\vdots$
$\vdots$
5

$\frac{5}{3}$

$\approx$

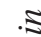

난

$\vdots$

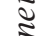

ธับ

ปิ

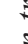

ำ

ミ

है

.

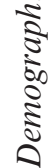

ริ) 
inter-city connections enlarge the accessible labour market and increase business-to-business interaction, which are key conditions for innovation. Hence, good railway infrastructures and services are critical. The problem is that the South Mediterranean countries have patchy networks, which the just beginning high-speed rail lines can hardly compensate for.

High speed rail is currently non-existent throughout the neighbourhoods, although several projects are planned. Morocco intends to create $1500 \mathrm{~km}$ of high-speed rail in the next two decades, to thoroughly modernise its old inter-city network, including, when financially and politically possible, an extension to the Algerian coast. An important difference between networks in the EU and those in the neighbourhood is transnational continuity. Along with political problems with crossing borders, there are incompatibilities between systems in terms of gauge and electrification. Some transnational projects aim to give continuity to the networks and thus to improve the relations between countries. One of these projects is a plan for high-level transport infrastructure (high-speed rail and motorway) linking the Maghreb coast from Casablanca, Morocco, to Tripoli in Libya. Such transnational projects are one of the main goals of the Euromed Transport Forum, a gathering of ministries of transport of the EuroMediterranean region.

Given the importance of Europe's energy needs and given the role of the neighbourhood as a key energy provider today and in the future (e.g. recent discoveries in the Eastern Mediterranean Sea and the Trans-Saharan gas pipeline project linking Algeria with gas fields in the Gulf of Guinea), actual and potential energy infrastructures could be the best driver for regional integration between Europe and its Mediterranean neighbours. However, achievement of such integration remains far from certain. The oil and natural gas network map shows the liquid natural gas export terminals in the Maghreb, related to the growing 'spot market' strategy of these countries, at the expense of long-term deliveries (by pipeline), thanks to the ever-growing reluctance of the European Commission to engage in longterm contracts. This shows that regional integration has been achieved with the Eastern neighbours to a greater extent than with the Southern neighbours. The influence of Russia on the European energy market is rising, despite growing European political concerns vis-à-vis Russia.

Map 1.3 on electricity networks shows the Medring project, which aims at connecting the North African countries between themselves and with European countries, using high voltage lines. A connection already exists between Maghreb and Western Europe, but at a lower voltage than what is mapped here. When it comes to the potential for solar power, there are enormous differences across the region. Radiation in the Sahara desert is on average 3.5 times greater than in the northernmost areas. Concentrated 


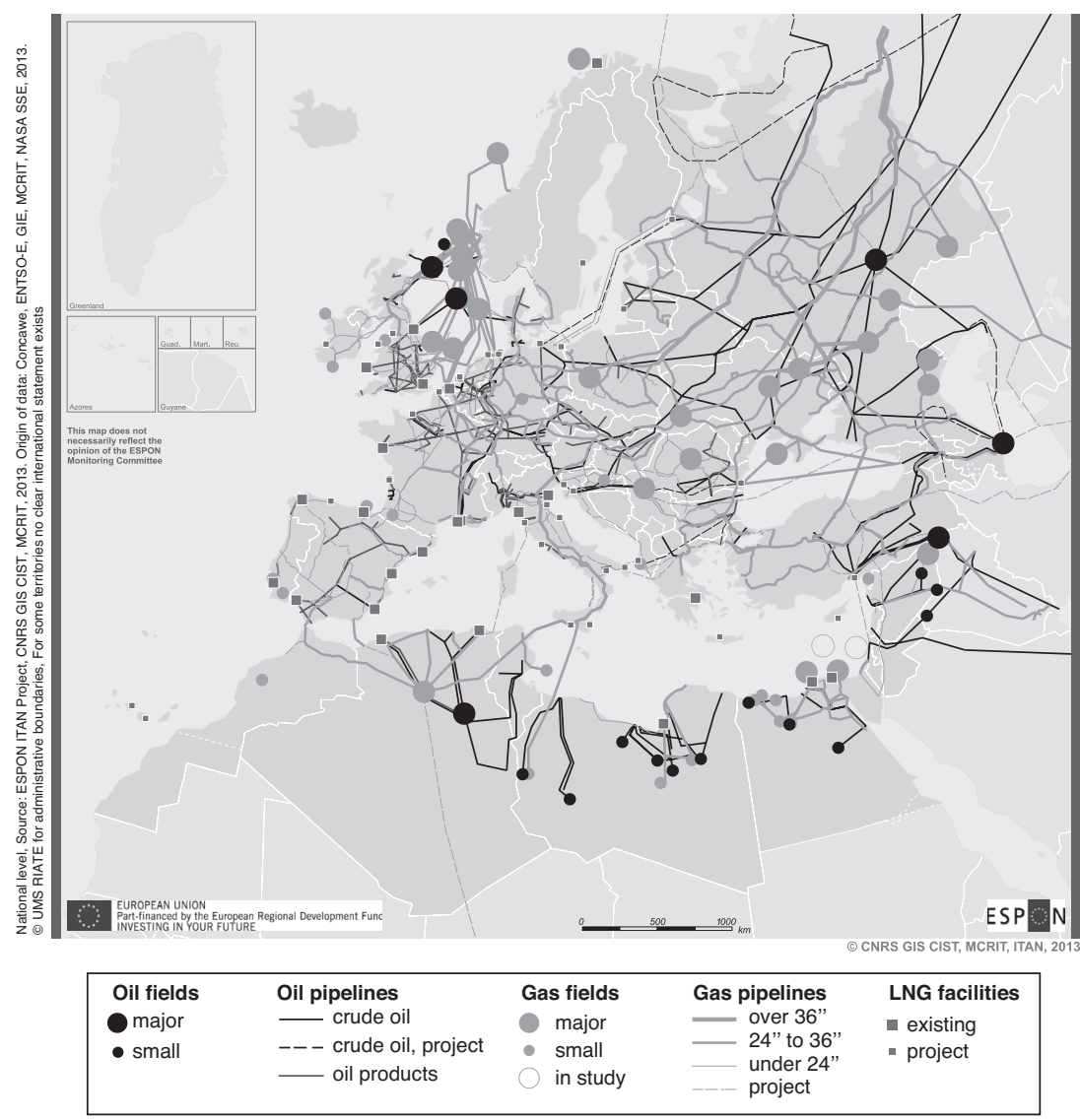

Map 1.2 Oil and gas networks in the wider European region, ca 2010

solar power stations (of more than $50 \mathrm{MW}$ ) are a relatively new technology that is not yet widespread. Most thermo-solar power plants are concentrated in the South of Spain (the Solúcar platform, at $183 \mathrm{MW}$, is the largest solar platform in Europe and is situated near Seville), while photovoltaic installations can be found in many places but are mainly concentrated in Germany. The solar electricity issue is addressed below in the section dedicated to the energy stake of the Mediterranean neighbourhood.

\subsubsection{The Mediterranean's External Flows: EU's Declining Role}

European influence around the world has declined over the years. As a result, European economic influence is more and more limited to its 


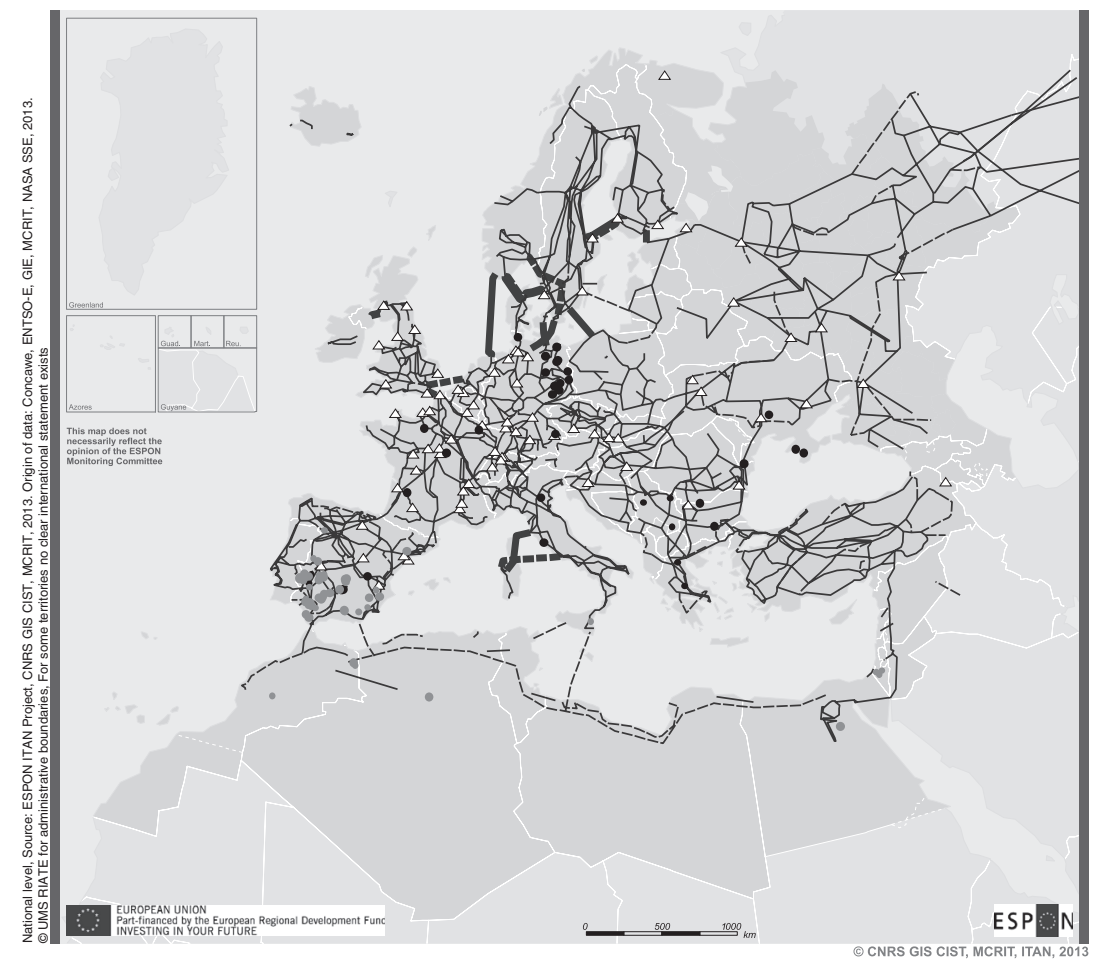

\begin{tabular}{|ll|}
\hline$\Delta$ nuclear power plant & \\
High voltage network & $\begin{array}{c}\text { Solar installations } \\
\text { photovoltaic }\end{array}$ \\
- transmission, $220-750 \mathrm{kv}$ & photovoltaic, UC \\
--- transmission, project & $\bullet$ thermosolar \\
\hline- Direct current line & $\bullet$ thermosolar, UC \\
\hline- Direct current line, project & \\
\hline
\end{tabular}

Map 1.3 Electricity network in the wider European region, ca 2010

immediate neighbourhood (Van Hamme et al. 2012). However, this does not mean that the neighbourhoods are the EU's most important partners. European neighbour countries represent $7.5 \%$ of European countries' trade and $11 \%$ of their potential market in the 2010 s decade, yet although they are shifting from a rent economy to a (slightly) more innovative economy, they hardly are a target for European investors. Neighbouring countries could be a significant driver for the European economy, their own development relying largely on Europe; nevertheless the 'NorthSouth region' remains economically less integrated than North America (including Mexico) and East Asia. 
European neighbourhoods, especially the Mediterranean neighbourhood, can be considered as the peripheries of Europe. Europe is more important to them than they are to Europe. The European Union appears as a cohesive area, with intense internal relations; Mediterranean neighbour countries (except Turkey) play a minor and dominated role in these relations (Van Hamme and Grasland 2012). Second, the trade relationship between Mediterranean neighbourhoods and Europe is imbalanced: high-level services and products vs primary or low added value manufacturing goods. Libya and Algeria have an exclusive specialisation in primary goods, mainly oil and gas. In contrast, some countries are moving from a purely peripheral position, mainly selling primary goods, towards specialisation in low added value manufactured goods: Tunisia and especially Turkey are the best examples, Egypt being less clearly engaged on this path, while Morocco is still highly specialised in mining and agricultural products despite the recent relocation of electronics and aeronautics plans here.

Table 1.2 shows the evolution of the importance of the EU, the neighbourhoods and the rest of the world for the different neighbourhoods. Most figures illustrate the declining importance of the EU in its neighbours' flows, although the EU is still the major partner of these neighbour countries. Map 1.4 on goods trade shows the importance of the EU for world regions and the importance of world regions for the EU. Mediterranean neighbours appear very dependent on Europe, with a high share of their flows turned towards their big neighbour, but are modest partners for the EU. However, the Near East is little oriented towards Europe. As a whole, the contrast is striking between the Western Balkans, more and more integrated to the EU's space, and the South Mediterranean neighbours whose economic links with Western Europe have declined in the last two decades, at a time when these countries applied the Association agreements with Europe and opened their markets to international exchanges.

In the ITAN project we have also computed sea trade data. In the case of container flows in vessel movements in 1996 and 2006, the share of Europe in North Africa's total traffic was the highest compared with other world regions, followed by western Africa and southern America. It has, however, reduced from over 50 to $40 \%$, owing to the rising imports of manufactured goods from Asian countries rather than from Europe, which is a general tendency of many world regions. A similar pattern appears when considering all commodity flows (containers, bulks, vehicles, general cargo): in 2004 more than $50 \%$ of North Africa's traffics were with European countries, but data for 2011 confirm the drastic shrinkage of Europe's share.

Table 1.2 also confirms that relations between Southern neighbours between themselves show very poor integration, despite the Agadir 


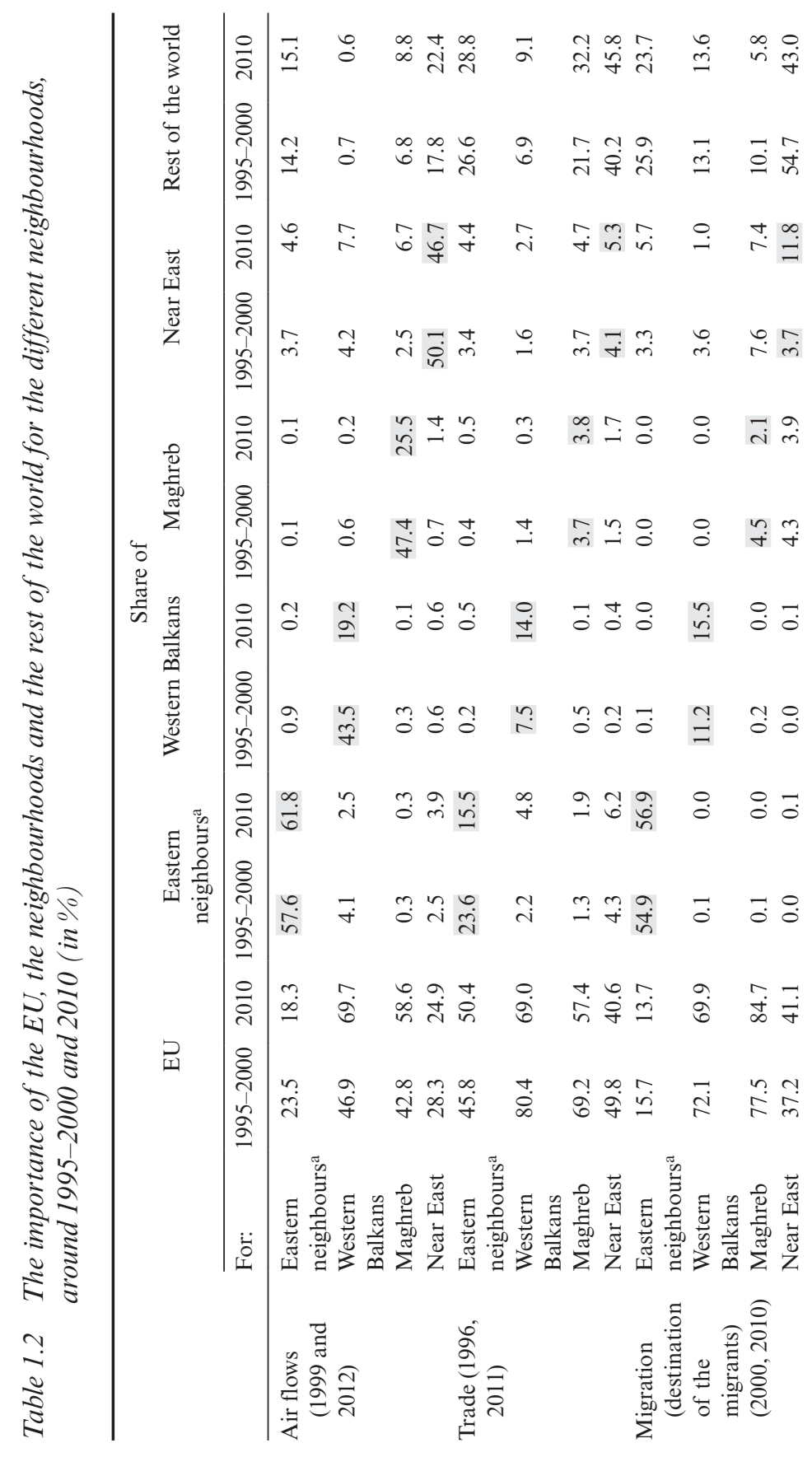




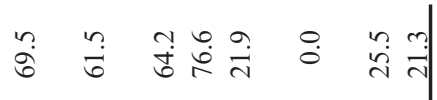

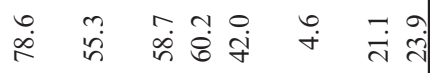

$$
\begin{aligned}
& \text { サ. }
\end{aligned}
$$

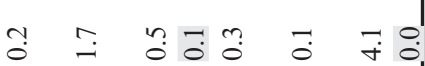

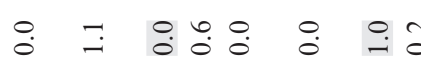

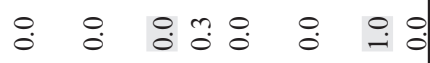

$$
\begin{aligned}
& \text { I }
\end{aligned}
$$

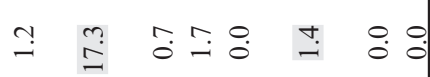

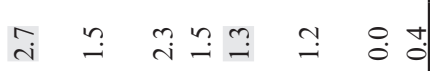

$$
\begin{aligned}
& \text { I }
\end{aligned}
$$

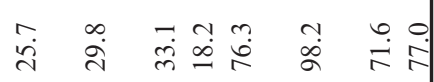

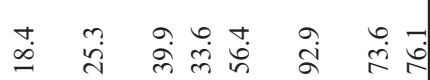

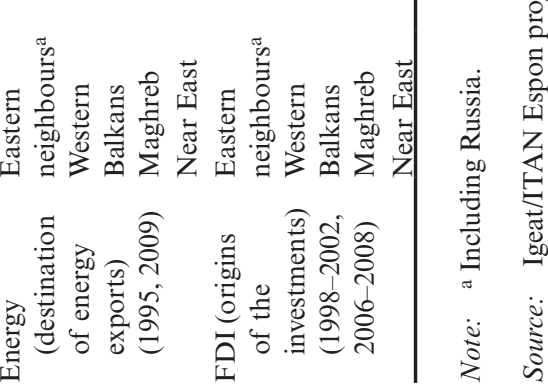




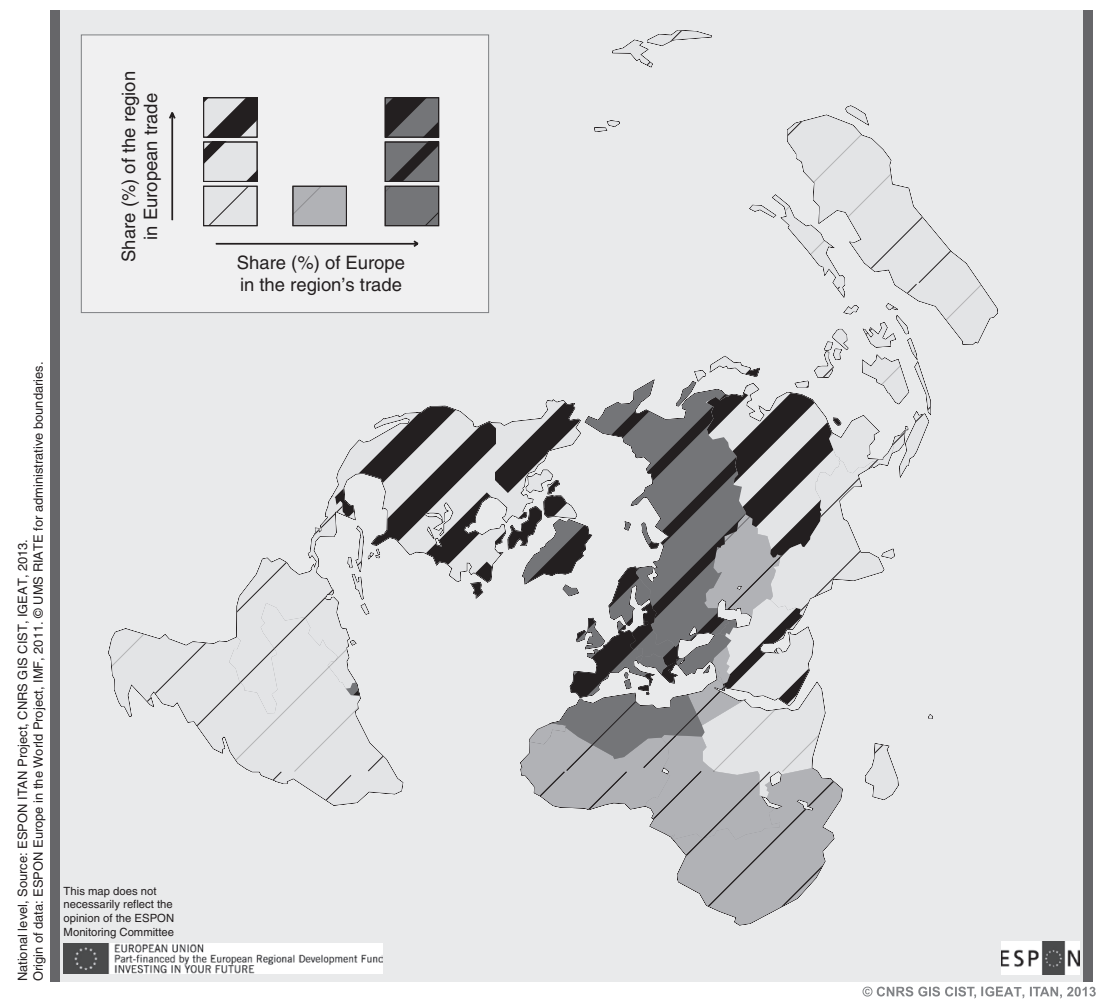

Map 1.4 Typology of the relationship between the EU and the regions of the world, goods trade 2011

agreements and the Greater Arab free trade agreement (GAFTA) launched in 2005, which were supposed to enhance inter-Arab trade. This market fragmentation serves as a further disincentive for foreign direct investment (FDI) in the region. It can be compared with the Eastern neighbourhood, which has moderate economic integration but intense human and related air traffic flows. In the Maghreb, integration is poor and stagnant. A similar pattern is found in the Near East despite an increase in human flows. Again, these figures were prior to the 2011 and the war in Syria; since then, the intense migration from Syria to neighbour countries of Lebanon, Jordan and Turkey has paradoxically increased the sub-regional integration of migration - in a desperate context of war and destruction. Traditional cross-border routes have been reactivated, because former cultural and family solidarity, which had diminished with the rise of the nation building in the second half of the 


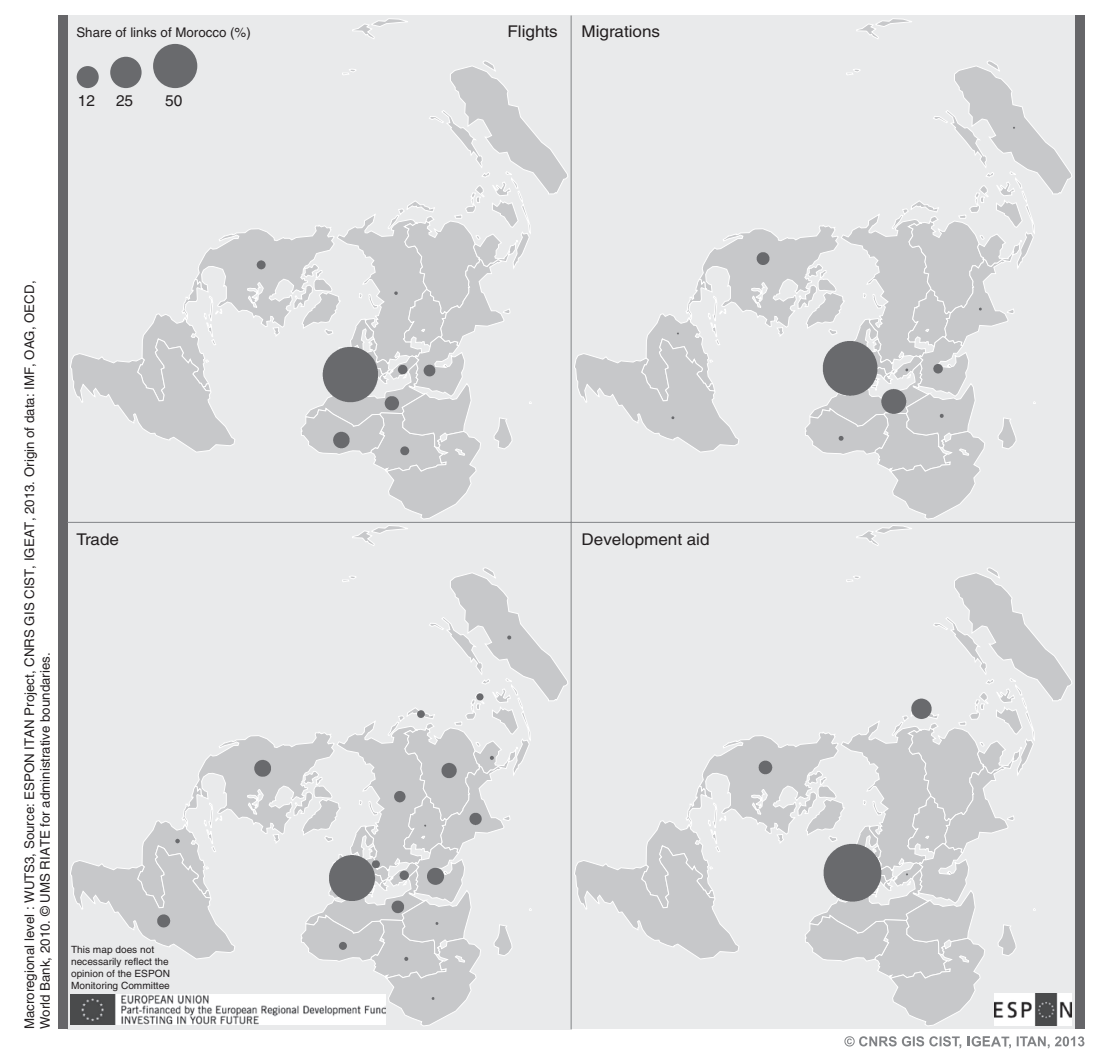

Map 1.5 The geography of global relations of Morocco, ca 2010

20th century, has been remobilised since the start of the war (Housseau 2015; Roullier 2015).

Turkey remains strongly polarised towards Europe, although less so than before. In the case of Morocco (Map 1.5), in all types of flows, Western Europe is the first partner. The country does not have another important partner and, in particular, relations with other Maghreb countries are very weak. The rise of South-South relations, and especially of intra-Maghreb relations (the border between Morocco and Algeria has remained closed since 1994, even though negotiations are on the agenda to eventually reopen this border), was one of the goals of the Barcelona process; it failed, even if there were slight improvements at the end of the 2000s and the beginning of the 2010s (CMI, World Bank and Islamic Development Bank 2012). The situation is similar for Tunisia, and, to a lesser extent Libya and Algeria. In the latter case, the lesser importance of Europe is the result of a political choice 


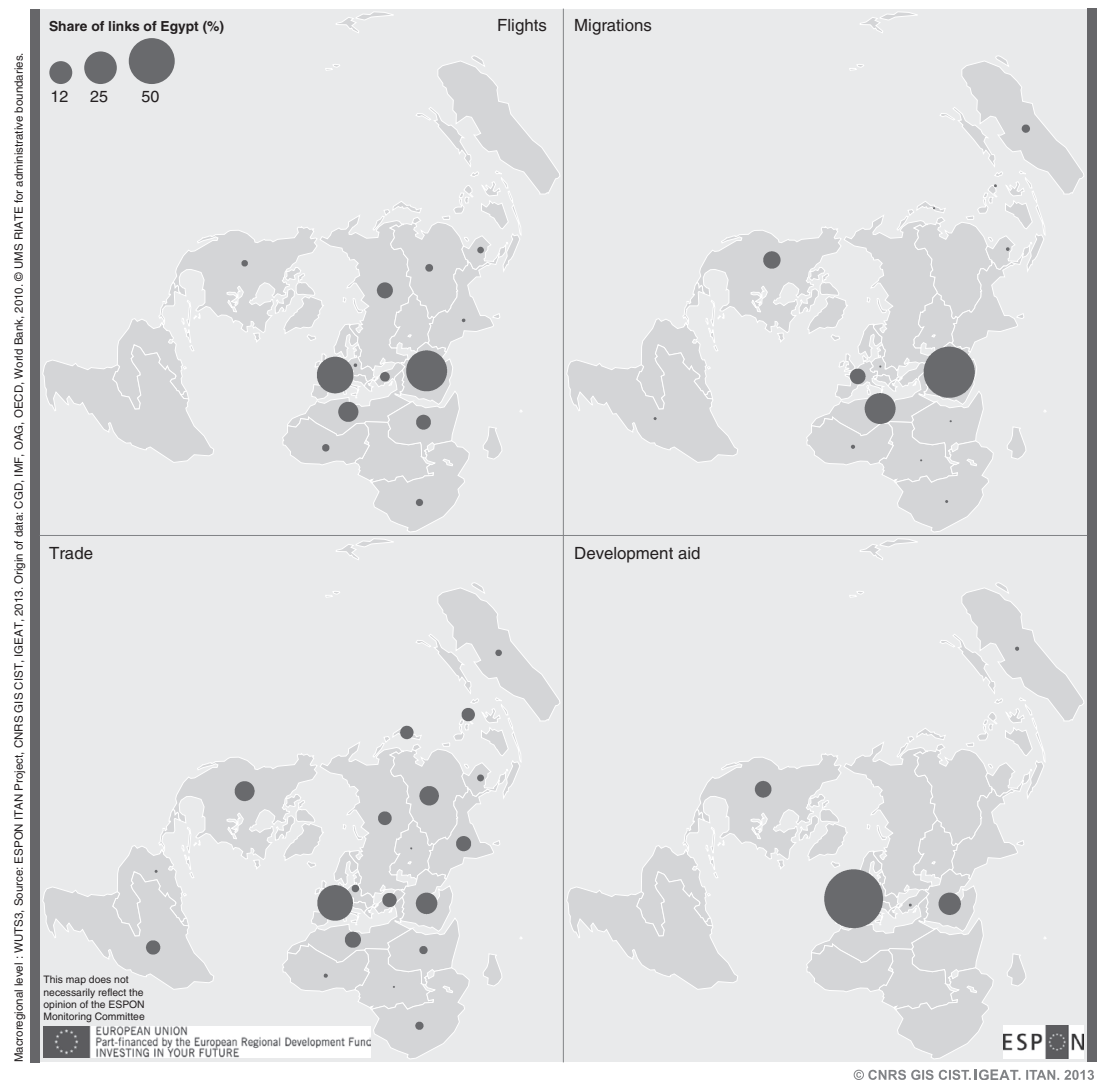

Map 1.6 The geography of relations of Egypt, ca 2010

to sell oil resources not only to Europe but also to the US; the Algerian state has deliberately diversified the geography of its energy exports, with Europe and the US accounting each for around 40\% of Algerian energy exports in recent years. As for Egypt, economic flows are still dominated by Europe but in terms of flight connections and migrations, its relations with the Middle East have become central - Egypt has been a major source of foreigner labour for Gulf countries for the last three decades (Map 1.6).

In the Near East, the low share of Europe in global flows is the result of the European decline versus the increasing importance of the oil powers of the Gulf in this region. The Jordan case illustrates this (Map 1.7). However, the EU remains an important partner for trade and the second largest donator of development aid, behind the US. The Mediterranean in general and the Near East in particular are clearly no longer polarised 


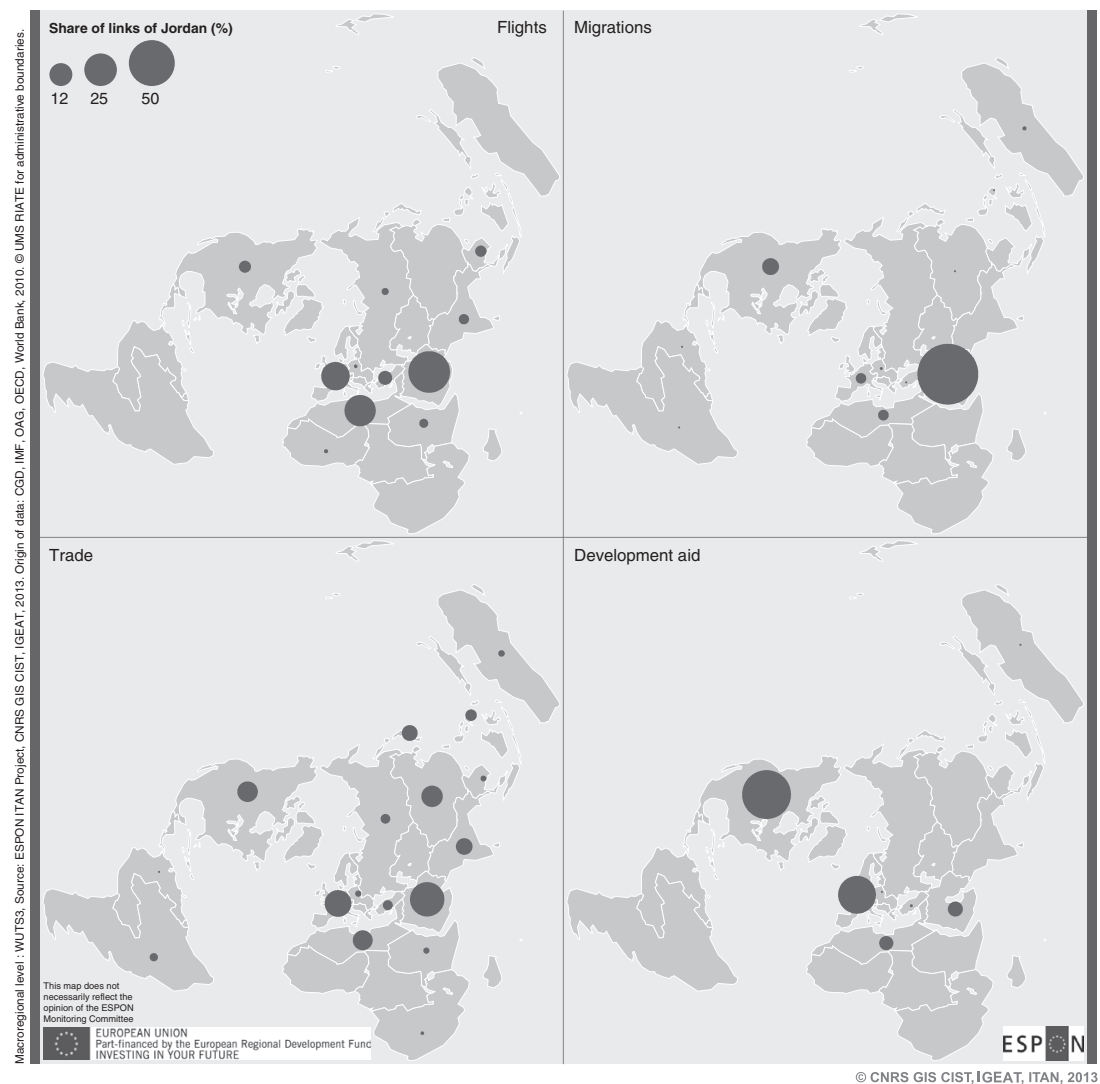

Map 1.7 The geography of relations of Jordan, ca 2010

by Europe. This could be seen as an asset: the South Mediterranean countries have taken advantage of globalisation to diversify their partnerships. However, this can also be seen as a shortcoming of Europe, that it is unable to set up a strategic vision and act to maintain a prominent role in its neighbourhood. Finally, the Israeli position is characterised by close links with the US. In the Near East, in the last two decades (1990-2012), we have observed a reorientation of air traffic flows towards the Middle East, mainly at the disadvantage of Western Europe, for Jordan, Syria and Lebanon. The decline of Western Europe for flight connections with Israel and Turkey has also been confirmed, though it has led to diversification rather than the emergence of a new polarisation.

Ironically, these Gulf countries remain the geopolitical allies of the EU in the area, even though their cultural references and the way they exert 
their rising influence upon the Near East (rent economy, investment in beach touristic resorts, destabilisation of the local productive activities owing to the flood of money, informal economy) contribute to the reduction of European influence (Abdallah 2011).

\subsection{HIGH LEVEL OF BUSINESS OPPORTUNITIES BUT LOW LEVEL OF PRODUCTION COOPERATION}

\subsubsection{Long Trend Factors in Favour of Euro-Mediterranean Economic Integration}

In this section we try to understand why the neighbourhoods could represent, as we said, more than $11 \%$ of the global potential growth for Europe in the coming decade. Wars in Libya and Syria and major political unrest in several other Arab countries hamper this economic potential. Yet one has to consider the long-term trends to anticipate if and how Europe's Mediterranean neighbours could one day become Europe's Tigers, far beyond their traditional role limited to low-cost industries, energy supply and cheap sun holidays.

The first factor is about demographic growth, and thus market potential. In 2025 the Mediterranean population could exceed 340 million, and 460 million including the Arab Peninsula and Iraq, that is to say with the Arabic lengthening of the Mediterranean neighbourhood. The contrast in demographic growth is impressive between south-eastern Europe and western Turkey (Map 1.8). Map 1.9 shows the age groups in the wider region, with a striking contrast between Europe - with many elderly people - and the South Mediterranean - with many young people - despite the largely advanced demographic transition. These young adults are ready for development or for unrest if the country does not offer them the jobs they need. Many revolutions in history have occurred in this peculiar demographic moment ('demographic gift'), including the Arab Spring which Courbage and Todd (2007) predicted and interpreted according to the demographic transition and political regimes.

The second factor is that Europe benefits from an important diaspora coming from its Mediterranean neighbourhoods (Table 1.3), in spite of the serious barriers the EU puts in the way of immigration from the Mediterranean neighbourhood, and in spite of the Europeans' difficulty in turning the 'immigration' paradigm into a 'mobility' paradigm.

The third factor is the actual economic growth of the South and East Mediterranean countries. Table 1.4 compares the GDP growth since 1980 in the various European neighbourhoods. It also considers the Gulf 


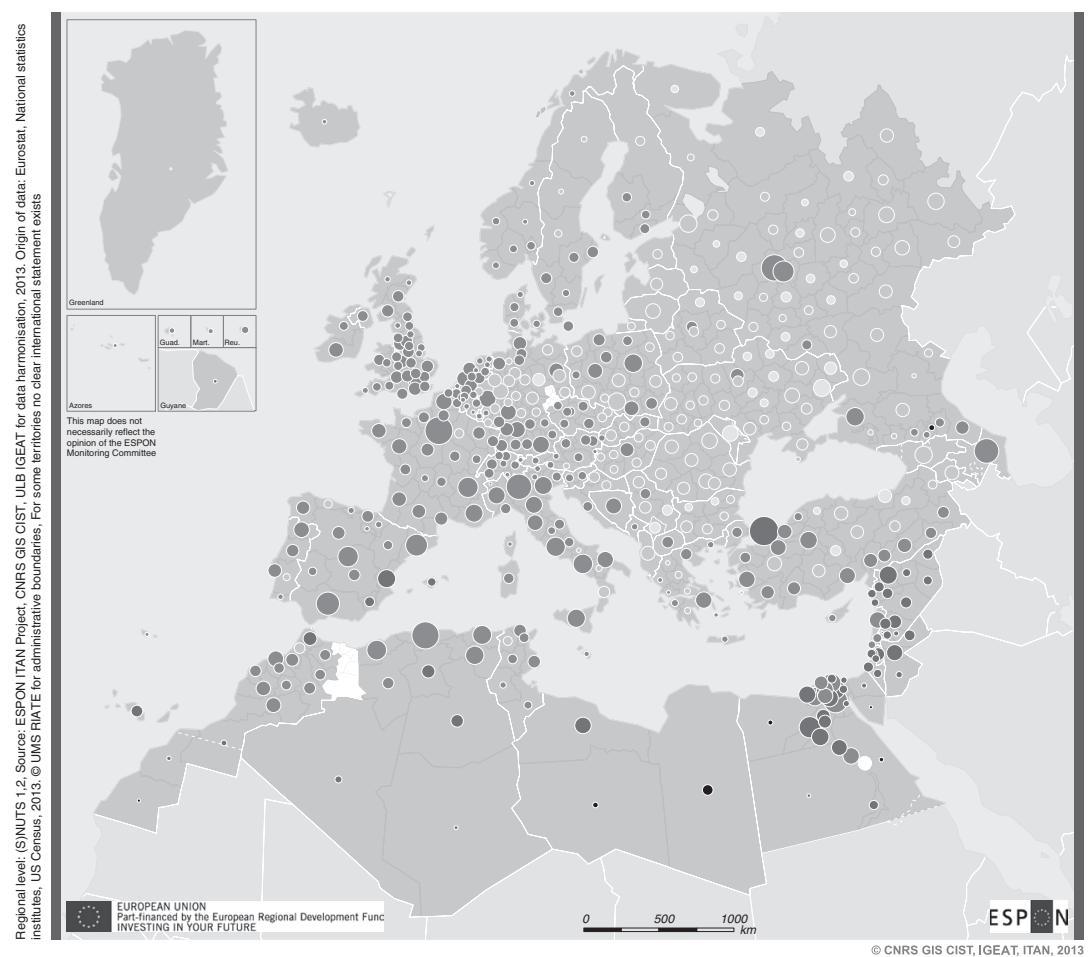

To calculate the annual growth rate of population, available data closest year of 2000 and 2010 are used. Collected data from the national institutes all over the countries covered by the project are quite disparate in terms of nature, definition, quality and time coverage. Therefore, data are harmonised against the national values provided by US Census. A cross-multiplication is used to apply the observed ratio at the regional scale.

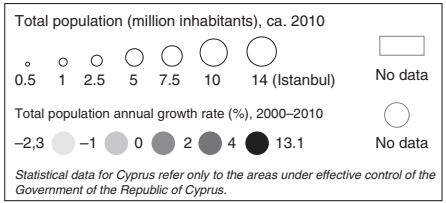

Map 1.8 The demographic growth in the wider European region, 2000-2010

countries plus Iraq and Iran, and the EU new Member States (2004-2007) because prior to 2004 they were Europe's neighbours. The rise of the Mediterranean region is impressive, whereas European decision-makers all too often regard their Eastern neighbours as the only significant economic partners. However, it has to be said that the rising rank of the Mediterranean neighbourhood's economy is mainly caused by the dynamism of Turkey and Israel, whereas the growth of Arab countries is more sluggish. Nevertheless, the analysis of the Moroccan case in the Gibraltar case study in Chapter 4 confirms the long-term rise of the Mediterranean 


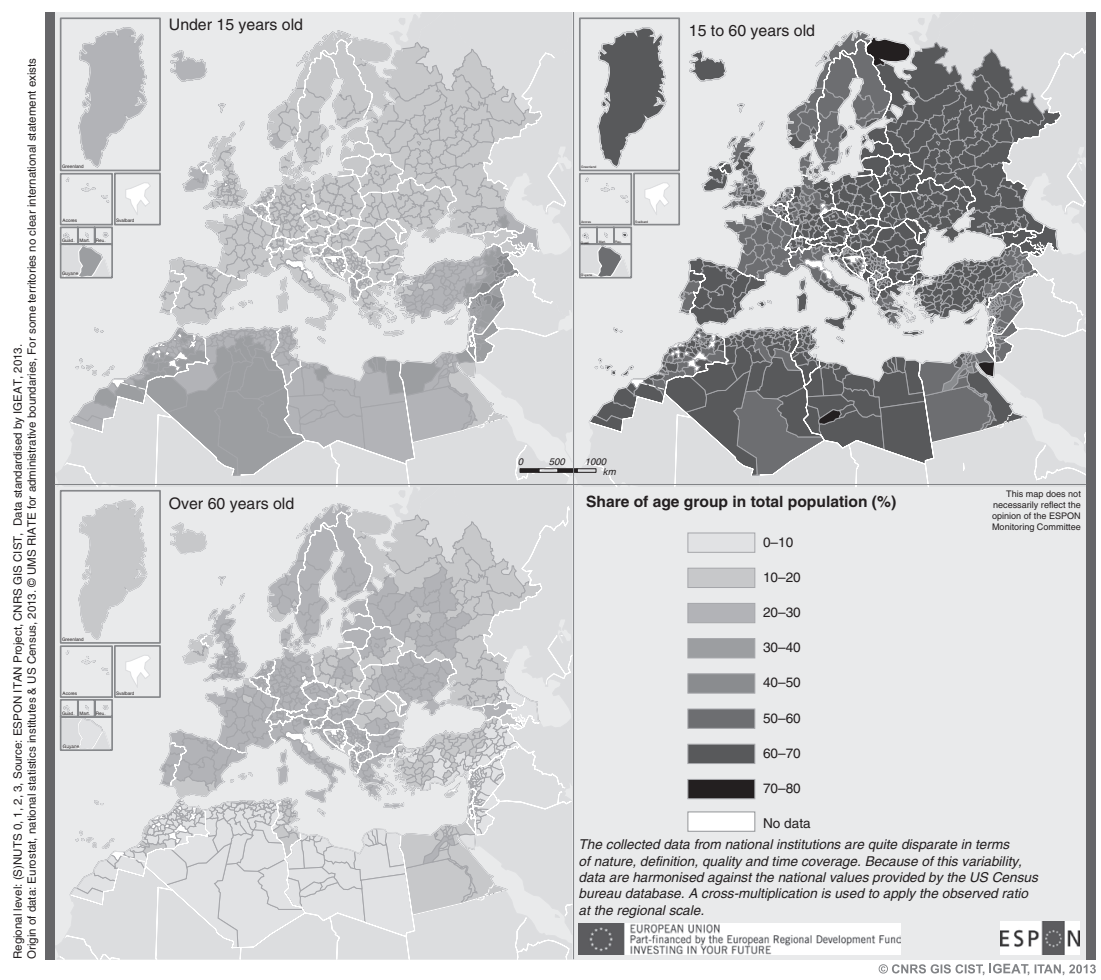

Map 1.9 Age groups in the wider European region, ca 2010

economies. Within the European neighbourhoods, the economic future seems to lie rather in the South than in the East.

The fourth factor is the huge potential for foreign, namely European, investment in the South Mediterranean economies (Figure 1.1). Despite their enormous financial needs for basic infrastructures (transport, energy, water, sanitation, telecommunication, etc.) and for business support, the Mediterranean neighbours remain marginal players in the world's FDI inflows. Circa 2000, Japanese investors targeted East Asian countries for one-third of their FDI outflows. A decade later, the figure has slightly changed with a declining number of East Asian countries, but it is still possible to say that Japanese companies invest strongly in their neighbouring region, and this began more than half a century ago. When one agglomerates all the FDI outflowing from any East Asian country, including South Korea, China and Singapore, the regional integration is very high since the region attracts half of these outflows. When it comes to the US, it invested in their region considerably in 2000 , but this declined over the 2000 s 
Table 1.3 A large proportion of the foreigners who live in Europe come from the neighbourhoods (in a wide sense)

\begin{tabular}{lrrr}
\hline & 1960 & 1990 & 2010 \\
\hline Western Europe & 34.1 & 31.1 & 26.1 \\
EU new Member States (2004-2007) & 34.6 & 16.7 & 11.9 \\
$\quad$ Western Balkans, Eastern neighbourhood, & 6.7 & 9.8 & 9.6 \\
$\quad$ Russia & & & 18.8 \\
South and East Mediterranean neighbour & 9.5 & 21 & \\
$\quad$ countries & & & 1.8 \\
$\quad$ Gulf States, Iraq, Iran & 0.4 & 0.9 & 8.1 \\
Sub-Saharan Africa & 1.5 & 5.2 & \\
\hline
\end{tabular}

Source: World Bank, 'Bilateral Migration and Remittances'/Igeat.

Table 1.4 The neighbourhood, a driver for Europe's economic growth. GDP in billion constant $2005 \$$

\begin{tabular}{lrrrrc}
\hline & 1980 & 1990 & 2000 & 2012 & $\Delta^{\mathrm{b}}$ \\
\hline EU new member States (2004-2007) & 549 & 595 & 667 & 986 & 1.8 \\
Western Balkans & 111 & 103 & 81 & 112 & 0.1 \\
$\begin{array}{l}\text { Eastern Neighbourhood + Russia } \\
\begin{array}{l}\text { South and East Mediterranean } \\
\quad \text { neighbour countries }\end{array}\end{array}$ & 888 & 1037 & 664 & 1169 & 0.9 \\
$\begin{array}{l}\text { South and East Mediterranean Arab } \\
\quad \text { neighbour countries }\end{array}$ & 182 & 568 & 829 & 1309 & 3.8 \\
\begin{tabular}{l} 
Gulf States, Iraq, Iran \\
\hline
\end{tabular} & 482 & 491 & 713 & 1252 & 3.0 \\
\hline
\end{tabular}

Notes: ${ }^{a}$ Without Turkey and Israel; ${ }^{\mathrm{b}}$ annual average growth (\%).

Source: CNUCED, UNCTADstat, Angus Maddisson.

because it invested more in Russia, Central Asia, Turkey and South Asia but mainly in China and Europe. The synthetic figures are clear: at the end of the 2000s, the emerging and developing countries of the related region attracted $21 \%$ of Japan FDI outflows and $10 \%$ of US FDI outflows, but only $4 \%$ of European FDI outflows.

Figure 1.2 gives an idea of the usefulness of the ITAN indicators. It crosses FDI inflows at a local scale with the local index of territorial dynamics based on local GDP and population growth. That kind of method is relevant for checking if all of the dynamic territories of the neighbourhoods are regarded as such by European investors. Minsk or 


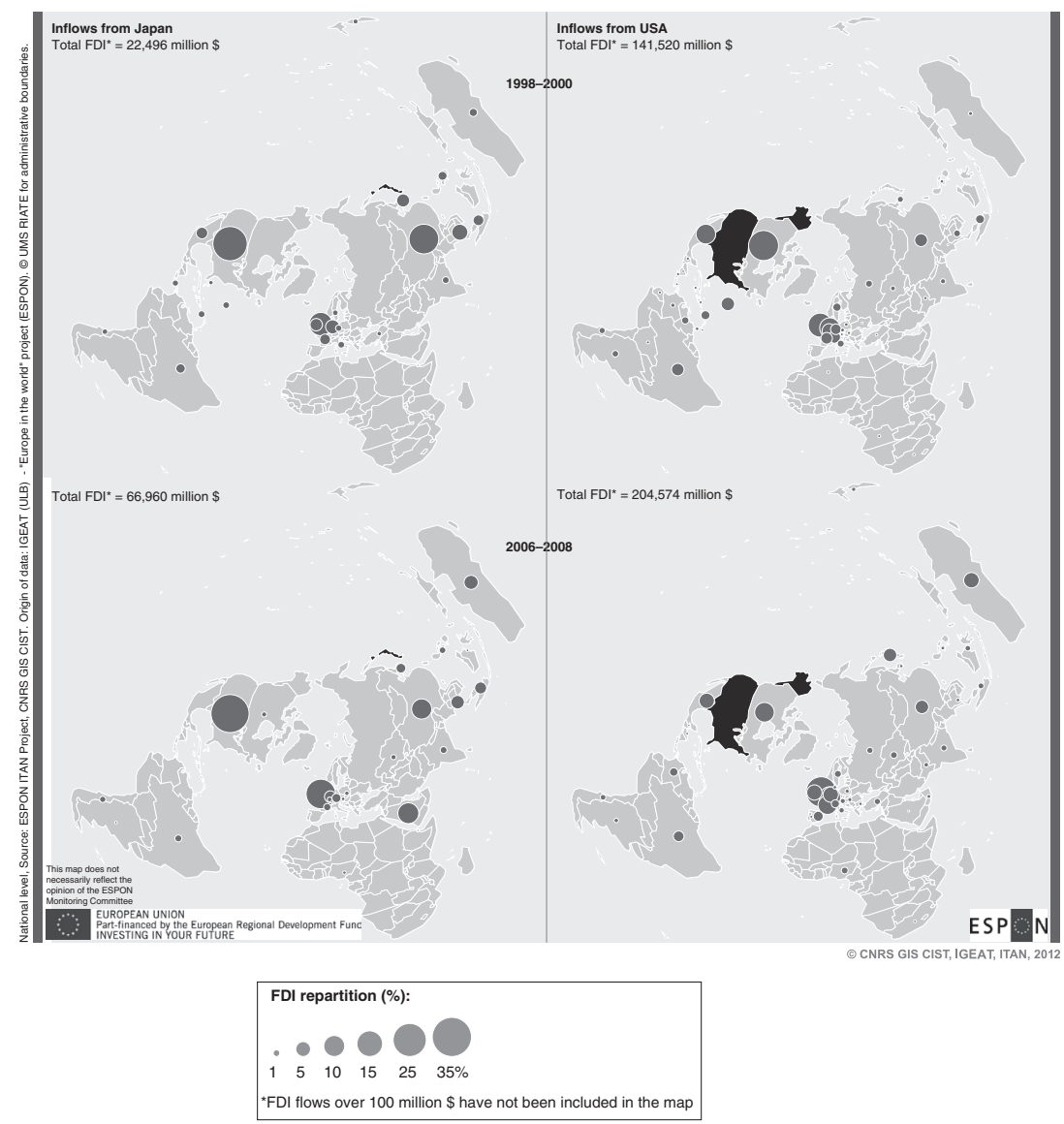

Map 1.10 The US and Japan investments in the region. Destination of FDI, 1998-2008

Kiev, quite dynamic territories of the Eastern neighbourhood, attract FDI; the same goes for numerous territories of the Mediterranean neighbourhood, including Syria (Damascus, Der ez-Zor, Tartous, Homs, Latakia, Aleppo; data are averages for the 2008-2012 period, the situation has changed profoundly since then). Nevertheless, many local territories in the Mediterranean neighbourhood and particularly in Egypt, show dynamic growth, which means a need for further equipment and services with at least potentially rising purchasing power, but show little or no attraction for foreign investors. This can be partly explained by the lack of information in Europe on the situation in Mediterranean neighbouring countries.

Indeed, since 2011 economic figures have worsened. The potential is 


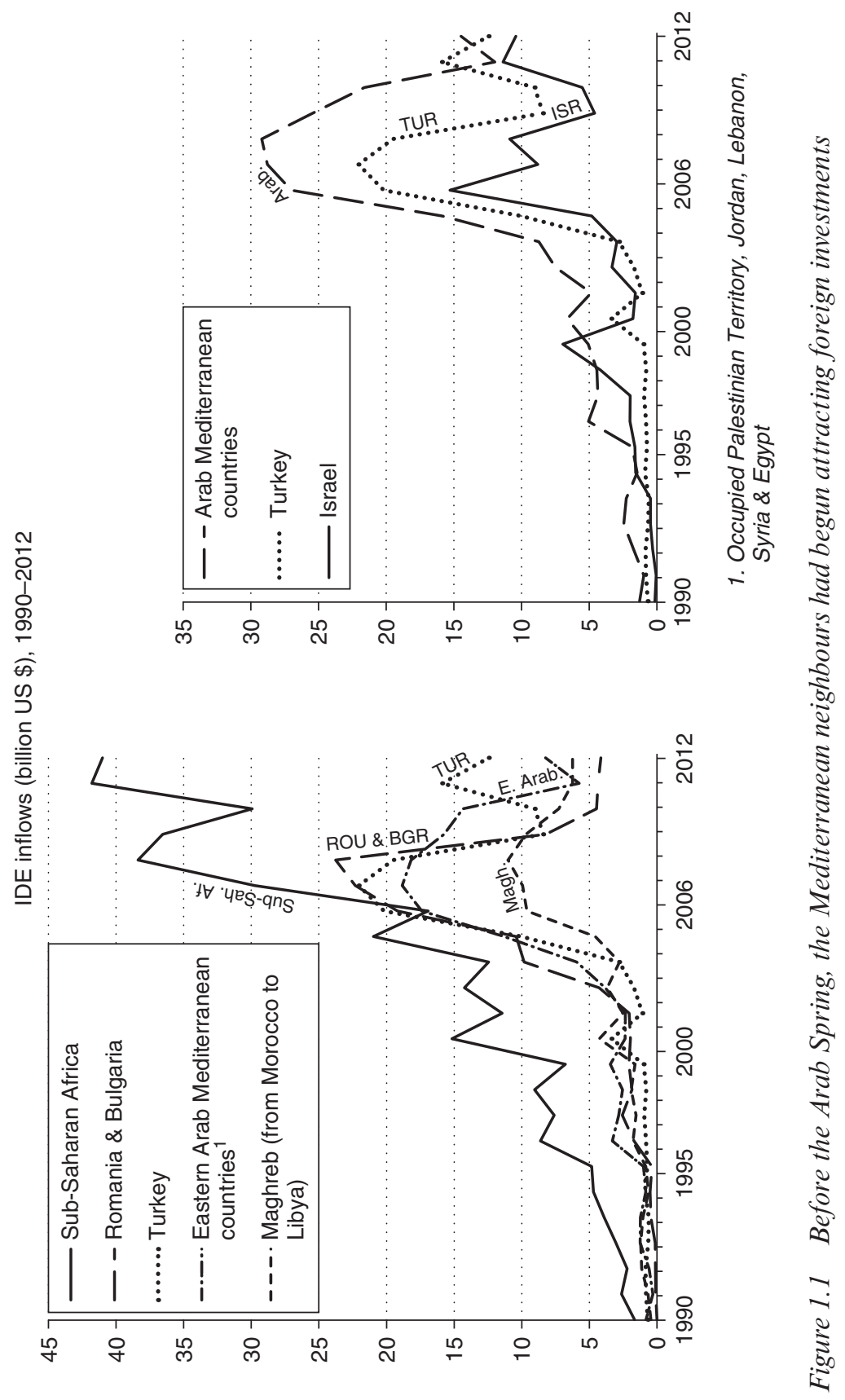




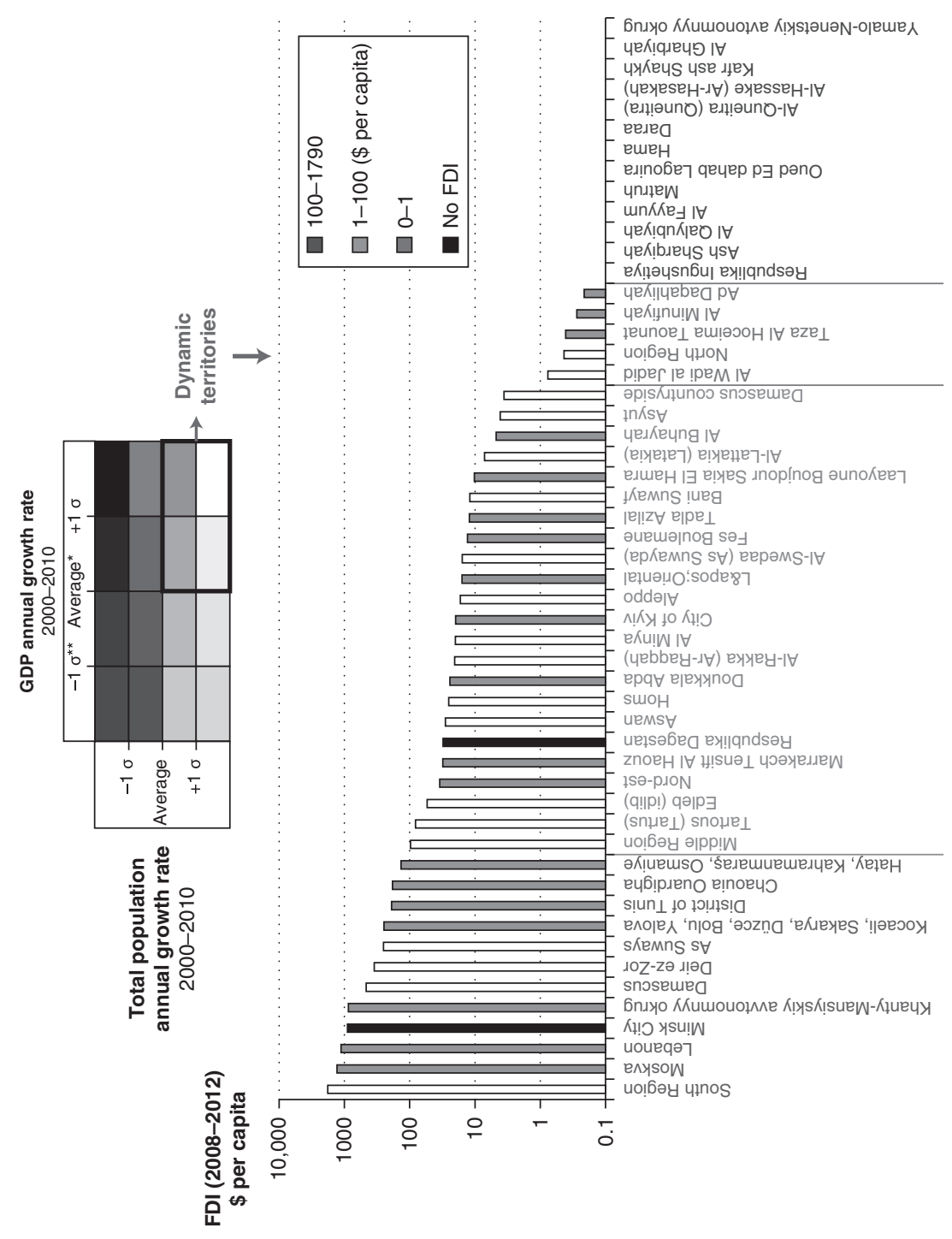

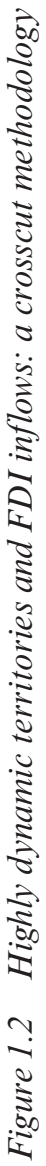




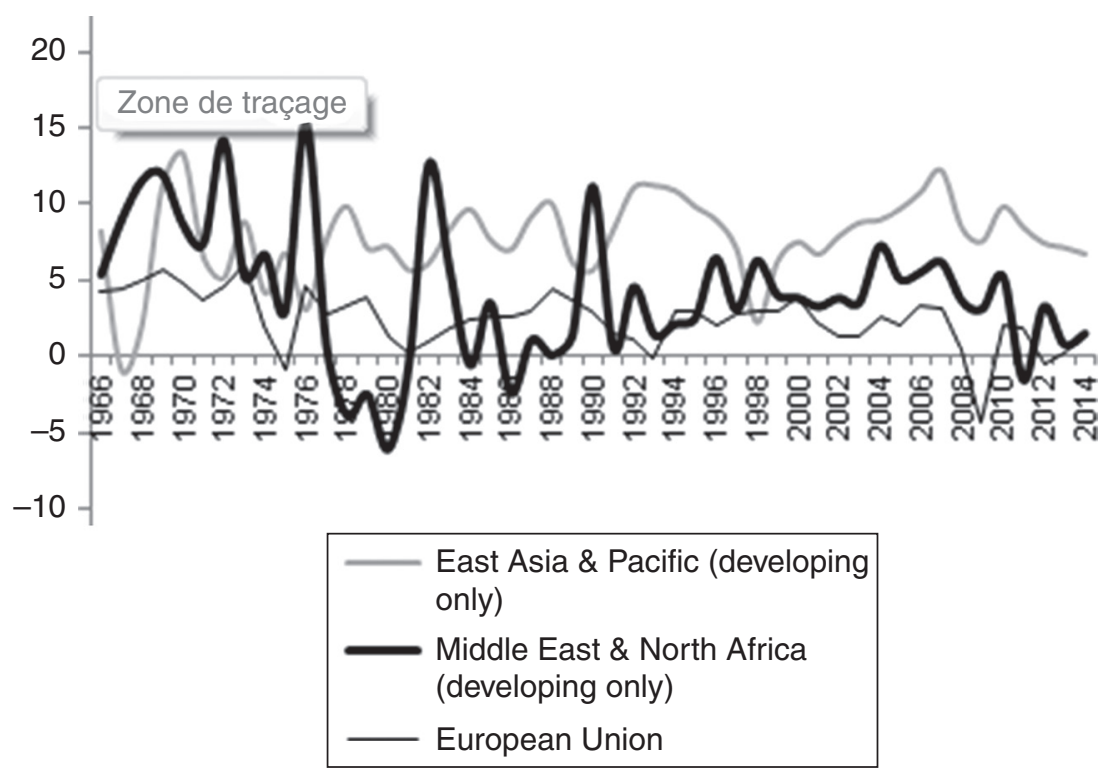

Note: Annual percentage growth rate of GDP at market prices, based on constant local currency.

Source: World Bank Online, http://data.worldbank.org/.

Figure 1.3 GDP change at constant price. Developing Arab countries far away from the booming Asian Dragons

there, but the reality is entangled in a very difficult transition. Figure 1.3 shows that the Arab developing countries' GDP growth kept pace with that of the Asia Dragons in the 1960s; since then, Arab growth has been more erratic and limited (less than 5\% per year) than that of its Asian counterparts (around 10\%). The international crisis in 2008 did not directly affect the Mediterranean partner countries owing to their tightly controlled capital accounts. However, the recession in Europe drove down foreign demand for their exports, migrant remittances and investment levels, because these international flows remain highly dependent on Europe's economy. When the revolutions burst out in 2011, these countries' economic growth was already in a difficult position. Since the start of the Arab Spring figures have dropped to $1 \%$, which is compatible neither with job creation nor with support for political transition.

Two European behaviours can derive from this situation. The first is to invest in a deep economic partnership with the Arab countries - typically 
Tunisia - where the political situation still allows economic projects, so as to help them give a perspective to the other Mediterranean neighbours. The second behaviour is to wait for political stability and full democracy before investing in these countries - with the risk that such European withdrawal could contribute to a long-run destabilization of the whole Mediterranean.

\subsubsection{The Economic Future of the Mediterranean Neighbours Relies on the Modernization of their Production Systems}

Over the last 15 years, the exports of Mediterranean neighbours have increased exponentially, but imports have increased even more. With the exception of the hydrocarbon-producing countries, merchandise trade surpluses have declined dramatically since 2001, particularly in relation to Europe, evidence that their production systems have not been adapted to the new global technological environment (Galal and Reiffers 2009). Table 1.5 shows this trade decline (in favour of Europe's trade balance), very far from the subsidy amounts received from the European Union (less than $0.3 \%$ of the GDP of Morocco, Tunisia, Egypt, Jordan and Syria in the table). The crash of their trade balance $(-13.9 \%)$ contrasts with financial external resources based on a rent economy: tourism revenue $(8.5 \%$ of GDP) and migrant remittances (6.1\%). Without more competitive output and exports, the Mediterranean neighbours will not be able to address their trade balance rising deficit - all the more so as the Association Agreements with the EU urge them to reduce tariffs, and thus public revenue, on imports.

Have things changed in the 2010s? The answer is no, for political reasons (wars and conflicts) and also for economic reasons. The movement of Arab countries towards a more innovative and productive economy is real but low. By focusing on denationalisation and international openness at the expense of support for the local private sector, Europe's policy in the Mediterranean bears a share of the responsibility for the lack of thorough modernization of South Mediterranean economies. As a result, the integration of the Mediterranean continues to be more trade oriented than production oriented, and segmented, with North-South trade prevailing over South-South, non-tariff barriers in the North and even in the South persisting or expanding, distortions between countries in regards to taxes and subsidies, and market segmentation. In short, economic integration remains weak overall and shallow rather than deep. The responsibility for this is shared by the North and the South. 
Table 1.5 Main external resources of Arab economies (current \$ billions)

\begin{tabular}{lrrr}
\hline & 1995 & 2001 & 2008 \\
\hline Algeria & & & \\
Migrant remittances received & 1.1 & 0.7 & 2.2 \\
FDI (net inflows) & 0.0 & 1.2 & 2.6 \\
Revenue from international tourism & 0.0 & 0.1 & 0.3 \\
Current account balance & -2.2 & 7.1 & 37.1 \\
Interest paid on external debt & 1.8 & 1.4 & 0.2 \\
Official Development Aid (ODA) & 0.3 & 0.2 & 0.3 \\
Incl. ODA received from European Commission & 0.0 & 0.1 & 0.1 \\
Other Arab economies & a & & \\
Migrant remittances received & & & \\
FDI (net inflows) & 7.7 & 9.3 & 22.8 \\
Revenue from international tourism & 1.1 & 1.5 & 19.5 \\
Merchandise trade balance & 8.5 & 11.2 & 31.4 \\
Interest paid on external debt & -13.7 & -12.9 & -51.2 \\
ODA & 3.8 & 2.9 & 2.9 \\
Incl. ODA received from European Commission & 3.5 & 2.8 & 3.9 \\
Turkey & 0.3 & 0.4 & 1.1 \\
Migrant remittances received & & & \\
FDI (net inflows) & 3.3 & 2.8 & 1.5 \\
Revenue from international tourism & 0.9 & 3.4 & 18.3 \\
Merchandise trade balance & 5.0 & 10.1 & 25.0 \\
Interest paid on external debt & -13.1 & -3.4 & -53.0 \\
ODA & 4.4 & 6.2 & 12.5 \\
Incl. ODA received from European Commission & 0.3 & 0.2 & 2.0 \\
\hline & 0.0 & 0.1 & 1.3 \\
\hline
\end{tabular}

Note: $\quad{ }^{a}$ Morocco, Tunisia, Egypt, Jordan, Syria.

Source: World Bank (except Algerian account balance: International Monetary Fund), author's calculations.

\subsection{EURO-MEDITERRANEAN POLICIES: SUCCESS OR FAILURE?}

\subsubsection{EU's Mediterranean Policies: Words and Facts}

We first briefly recap the main features of EU's Mediterranean policies. In 1995 the Barcelona Process was launched by the ministers of foreign affairs of the then 15 EU members and 14 Mediterranean partners, as the framework to manage both bilateral and regional relations. It formed the 
basis of the Euro-Mediterranean partnership. It was an innovative alliance based on the principles of joint ownership, dialogue and cooperation, seeking to create a Mediterranean region of peace, security and shared prosperity. These three main dimensions remain today as the pillars of the partnership: political and security dialogue; economic and financial partnership (focused on the gradual establishment of a free-trade area); and social, cultural and human partnership.

In 2003, Romano Prodi and Chris Patten laid out what would become the European Neighbourhood Policy. The former headed the European Commission. The latter had been the last governor of Hong Kong and could then observe the striking economic integration of the East Asian region. When he was appointed the European Commissioner for External Relations, he agreed with the Commission's president on the need to enlarge the regional vision of the European Union. The ENP was officially launched in 2007, with the official objective of 'achieving the closest possible political association and the greatest possible degree of economic integration' with Eastern and Southern neighbours; neighbours would share 'everything but institutions' with the EU. In practical terms, this meant (a) making the neighbours' norms and rule of law converge as much as possible with the EU's, (b) creating financial incentives, technical support and free trade, and (c) establishing programmes and tools that would unify the various previous policies of the EU with its Mediterranean and Eastern partners.

The continuing difficulties in the Mediterranean region led some decision-makers to propose adding another type of agreement that would be devoted to production partnerships and based on companies' involvement. Initiated by the French president in 2008, it finally became an EU agreement with 15 Mediterranean countries and the Arab League. Along with the impetus put on private actors and projects, the Union for the Mediterranean (UfM) emphasised the need for equal, shared North-South decisions.

Another institutional framework is the 'Dialogue $5+5$ ', which involves regular meetings of ministries, depending on the issue placed on the table: Foreign Affairs, Interior, Transport, Agriculture, Culture, etc. These meetings, which began as early as 1990, gather the representatives of western Mediterranean countries - Portugal, Spain, France, Italy and Malta for Europe - and the countries of the Arab Maghreb Union (a 'Union' in name only) - Algeria, Libya, Mauritania, Morocco and Tunisia. Because the Near East has been mired in the Israeli-Palestinian conflict and the Syrian war, the $5+5$ has been revived since the start of the Arab Spring, with ten ministerial meetings since 2011 and a head of government summit. It has to be added that the $5+5$ is only a forum, not a decision-making tool. 
What are the on-the-ground results of these policies? Among the 'four freedoms' that the EU shares with its neighbours according to the ENP, those of goods, services and capital have been widely promoted, whereas that of people has been widely hampered by the Europeans. Increased facilities were given to Eastern neighbours to alleviate the visa regime, but not to Southern ones. Only Turkey could take the opportunity, around the negotiation with the EU on the Syrian refugee crisis in 2016, to obtain a significant facilitation of visas for its nationals. In the Arab world, the feeling remains that no 'closest possible association' is in fact possible without freedom of movement.

When it comes to 'economic integration', the pattern of the EU has been largely dominated by free trade, with insufficient consideration for productive partnerships such as the Japanese have achieved with their own neighbours. It has to be said that Arab countries' governments themselves have been hardly capable of implementing efficient national policies for up-to-date professional training, R\&D and innovative industry. In itself, an economic partnership limited to trade hardly drives integration, and mostly increases the initial inequalities between national economies. Galal and Reiffers (2010) have summarised the findings of multiple studies on the real impact of the Euromed agreements in terms of regional trade: the gross trade arising from the Association Agreements amounts to an approximate increase of $25 \%$ over the period from 1980 to 2000 and this new trade has subsequently declined over time owing to (a) gradual elimination of the Multi-fibre Agreement (textiles and clothing) controlling the preferential margin that Mediterranean neighbours once enjoyed in comparison to Asian countries, (b) the EU's signing of preferential agreements with Eastern and Central European countries, (c) the effects of the EU's restrictive policy concerning agricultural trade on its Mediterranean neighbours' exports, and (d) the low technological level of South Mediterranean countries' exports and thus the difficulty of developing intra-industry trade and sharing the value chain between the North and the South.

When it comes to European subsidies to the Mediterranean partners, they are too scattered over an enormous variety of fields to really impact economies, social groups and territories (Beckouche, Besnard and Pecout 2016). During the 2007-2013 budget period, the ENP financial instrument (ENPI) was intended to be present in all development areas: trade, environment, climate change, peace and security, agriculture, fishing, health, education, professional training, employment, migration, research and innovation, information society, sound governance and taxation - not to speak of the gender balance, children's rights and defence of indigenous peoples! Moreover, it had an overall very limited 
amount of money. In Table 1.6, the total of the EU's subsidies and loans to neighbours is shown to be extremely limited: $€ 13$ per inhabitant of the Mediterranean neighbours, to be compared with the Eastern neighbour countries (€26), the applicant countries ( $€ 45$ for Turkey and $€ 145$ for the Western Balkans) and, above all, the new member states (€261). In addition, the amount per inhabitant dedicated to the Mediterranean region has decreased in the last two decades. It has to be acknowledged that this table does not take into account the subsidies of each member state of the EU, which as a whole spend much more public aid and subsidised loans than the EU as such. Yet given that these member states do not really have any neighbourhood strategy and scatter their financial intervention throughout the wide world, a consolidated picture would not change the result much.

Lastly, the UfM fails to raise money from the private sector, and actually relies on the financial and administrative processes of the European Commission. Indeed, it took years before the UfM's General Secretariat could be properly organized, could benefit from a budget worthy of the name and could appoint representatives of the European countries of its own choice. Hopefully the Secretariat is now in a condition capable of more meaningful action.

After the G8 summit at Deauville in 2011, a lot of money was promised to the Arab countries in transition, but since then, the 'Deauville partenariat' is far from having provided the promised $\$ 80$ billion. In particular, Tunisia regularly asks Europe for aid to help it tackle its transition and the insurgency at its Libyan border, but money is given sparingly.

In short, the perspective of an EU membership results in a high level of economic integration; this has been the case for the Central European countries, who became members in 2004, and today with Western Balkans countries. Conversely, the status of simple 'neighbours' has resulted in a declining economic integration with Europe, low levels of financial aid and insufficient solidarity with these transitional countries (Beckouche and Richard 2013).

\subsubsection{A Slow but Real Trend Towards Deep Integration}

This policy has four positive outcomes nevertheless. The first, as with the North American Free Trade Agreement (NAFTA), is the practice taken up by the governments of interacting with one another. This is important for the future insofar as political and business relations in the past consisted of a blend of collusion (access to certain markets facilitated through corruption and personal networks), fear and ignorance or even contempt. 


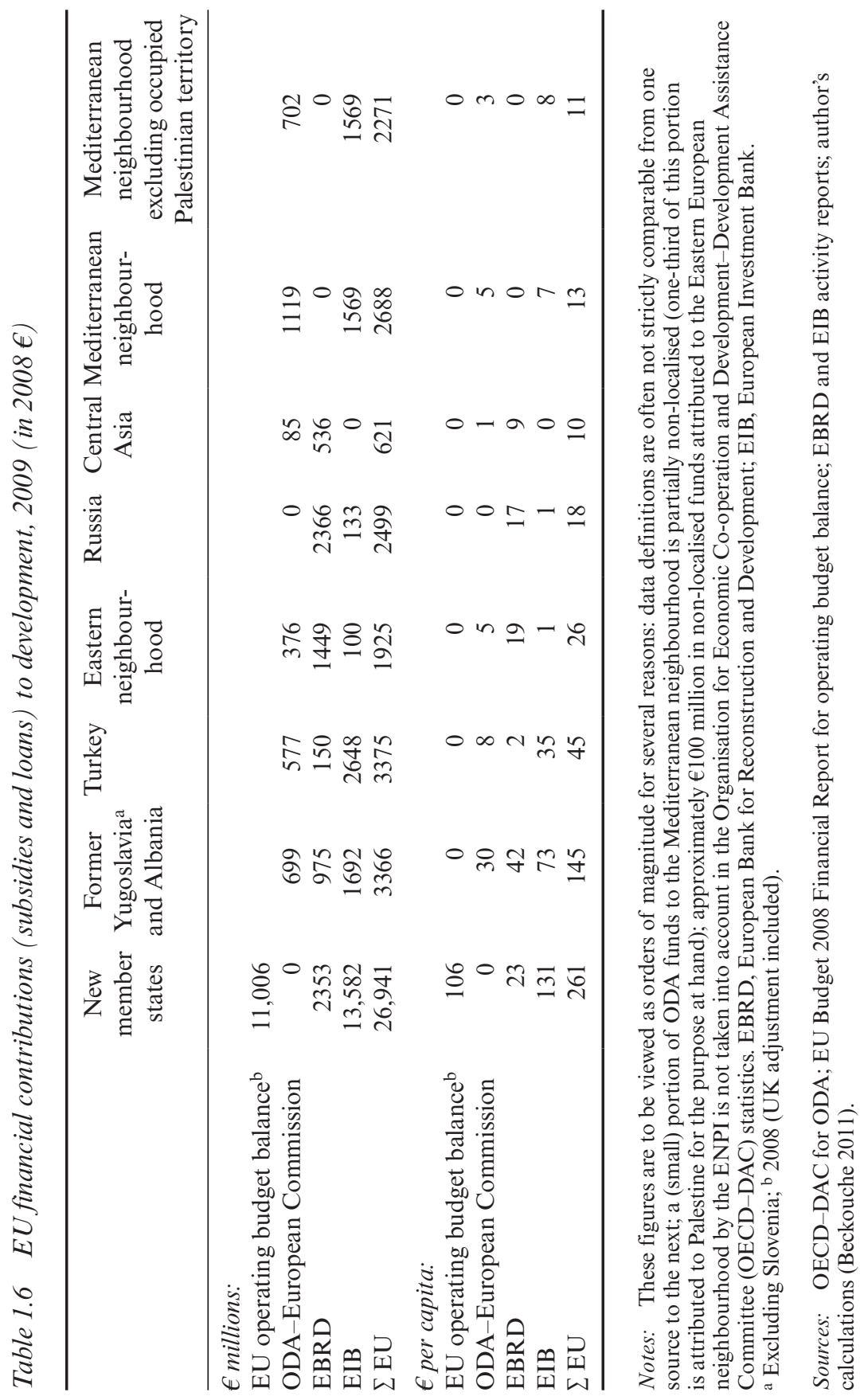


The second is openness to international commerce in the form of both trade and FDI: whereas South and East Mediterranean countries (SEMCs) accounted for just $1.8 \%$ of worldwide FDI in the early 2000s, this share rose to $2.5 \%$ in 2007 before dropping again after the 2008 crisis. Up until the Arab Spring, Association Agreements with the European Union played the role of national economic policy and helped South Mediterranean governments give priority to international openness and macroeconomic stabilisation.

As a result, the third positive outcome is this remarkable macroeconomic stabilisation. Since 1995, the South Mediterranean countries have largely paid off their debt - with the exception of Lebanon, where public debt plays a central role in the country's political economy as the means of redistributing public money to the various communities. Their inflation dropped from $5.3 \%$ of GDP to $3.1 \%$ (at least officially), and the investment rate increased from 24 to $28 \%$ at the beginning of the 2010 s. Until the Arab Spring, the annual economic growth rate was around 5\% and, just before the revolution burst out, the World Bank was forecasting growth rates in 2011 of 4.4\% in Morocco, 4\% in Algeria, 5\% in Tunisia, 6\% in Egypt, 7\% in Lebanon and 5.5\% in Syria.

The fourth positive outcome are the steps taken towards deep integration between the two sides of the Mediterranean, in the fields of financial activities, environment, energy and transport:

- The area is far from integrated in terms of the securing of investments that the United States successfully imposed on Mexico under NAFTA. However, banking consortia bringing together institutions on both shores are beginning to appear, investment capital actors have formed a network (Euromed Capital Forum) and financial market regulators have also established a Euro-Mediterranean network.

- Initiatives concerning the environment actually date much further back, as far as 1975 and the launch of the UNEP Mediterranean Action Plan. However, little progress has been made on one of that project's symbolic objectives, pollution reduction in the Mediterranean Sea. It took until 2008 and the launch of the EIB's Horizon 2020 programme before any significant and concerted action would start in regards to water sanitation in coastal areas. The UfM has made a priority of pollution control in the Mediterranean, confirming the importance of the environmental theme to regional integration. However the environment could also become a source of discord between the two shores as environmental standards increasingly create a non-tariff barrier blocking 
European markets to South Mediterranean agricultural exporters (e.g. possible European penalisation of imports coming by way of road transport).

- In 2003 the Barcelona process ministers opted to move towards integrated gas and electricity markets between the Mediterranean neighbours and Europe. National agencies responsible for energy savings and renewable energy formed a regional network called MEDENER. The UfM's decision in 2008 to launch a Mediterranean Solar Plan targeting $20 \mathrm{GW}$ by 2020 presumes a certain heightening of cooperation in this regard, in terms of regulatory aspects, solar production and electrical interconnection infrastructures. The Euro-Mediterranean electricity loop is of utmost importance at the same time for the neighbours' development and for a good connection with Europe. It will interconnect the grids of all of the countries bordering the Mediterranean and is considered by the European Commission as a key priority. At present, there are three interconnected zones: Europe (Union for the Coordination of Electricity Transport - UCET) and Morocco, Algeria and Tunisia; Europe and Turkey; and the south-eastern Mediterranean block, which links the countries from Libya to Syria. There are still some barriers to a region-wide inter-connection, owing to different security standards from grid to grid. Addressing those issues will require, when politically possible, the creation of an interconnection between Turkey and Syria, and one between UCET and Egypt via Libya.

- Monitored by the European Commission, the Euromed Transport Forum, which gathers representatives of ministries of transport of Europe and the Mediterranean partner countries, held its first meeting in 1999. Since then it has created a joint master plan for transport infrastructures destined to cover the entire region (Regional Transport Action Plan, 2005a, b) and for financing of the first elements of this system. The Forum's 17 priority infrastructure projects were selected at the end of the 2000 s according to two ambitious regional criteria: intermodal, port and rail projects rather than road ones in order to address climate change; and projects of international dimensions, i.e. international connections and/or parts of transnational corridors. However, since the start of the Arab Spring, the activity of the Forum has dropped dramatically. Fortunately, the UfM have taken over some trans-Mediterranean transport projects. In particular, the Motorways of the Sea promotes better transport connections in the Mediterranean, through support to pilot projects, awareness raising, model building and information 


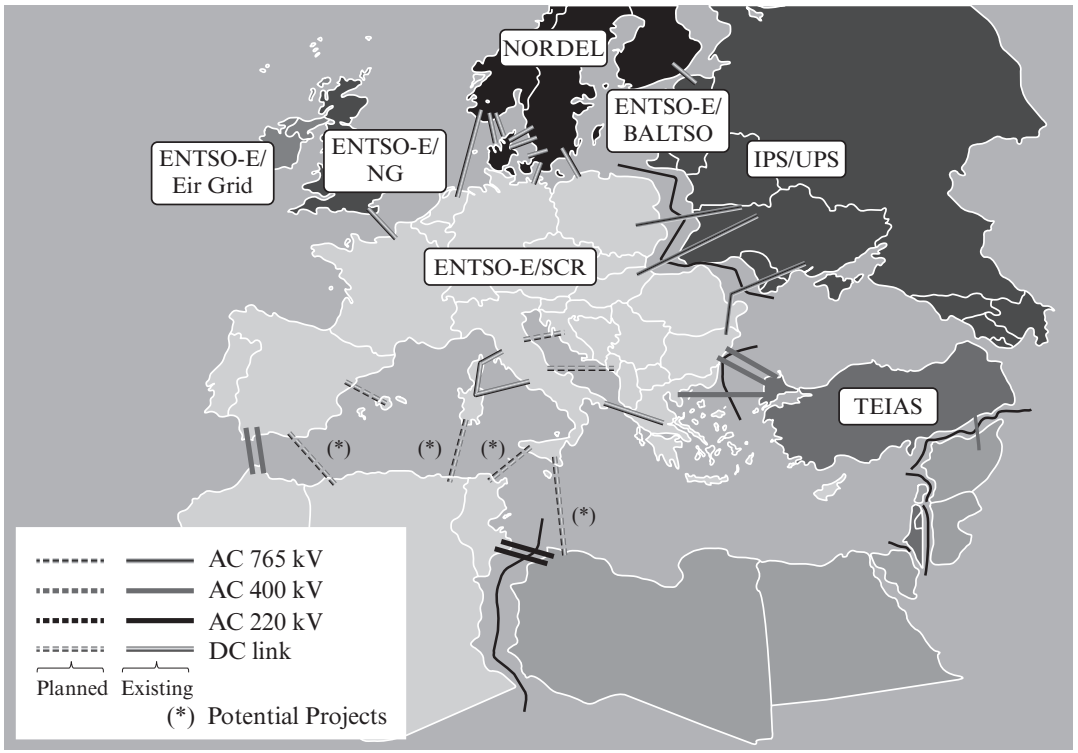

Source: OME.

\section{Map 1.11 The Mediterranean electricity loop to connect the European and neighbours' markets}

dissemination. The projects are of three kinds: (a) modal reports on transport by sea rather than road; (b) modernisation of port governance by exchanges of experiences and better coordination in information and procedures, in order to reduce logistics time; and (c) a planning dimension in order to expand and modernise port facilities in the neighbour countries.

A juxtaposition of projects will not be sufficient for a Mediterranean deep integration. Trans-Mediterranean common vision and policies are on the way. The political context makes the path narrow, but the foundations have been laid. If they were to be set up, an ambitious common policies could change many things:

- the type of supported projects, which would also be more coordinated;

- the type of funds - loans and investment capital rather than subsidies and budget support;

- the type of backed stakeholders, namely the private sector and 
small and medium-sized enterprises that get involved in common projects;

- the considered term - long-term instead of the short-termism of both the Arab countries' governments and the European decisionmakers vis-à-vis their Mediterranean neighbourhood.

In which field should such common policies be set up? The list has been known for a long time on both sides of the Mediterranean: a common energy policy; a food security policy; a common water strategy far beyond the de-pollution of the Mediterranean; and above all a liberalization of professional mobility instead of the counterproductive and humiliating hard visa regimes that prevail in the Euro-Mediterranean area.

\subsection{THE FIRST EURO-MEDITERRANEAN COMMON POLICY SHOULD BE ENERGY}

Given the resources in the Mediterranean region (hydrocarbons and solar), energy is a field of obvious complementarities with Europe: (a) making both supplies and commercial markets secure in the region, and decreasing Europe's rising dependency on Russia; (b) enhancing the immense industrial and technological potential for the whole region (more than \$200 billion is to be invested in energy in the Mediterranean neighbours in the coming decades) and sharing the value chain; and (c) promoting together the energy transition. Moreover, energy has much to do with territorial development: local access to electricity, which is a key condition for development; solar electricity for remote areas; energy saving by compact sustainable urbanism; cross-border cooperation thanks to shared energy transport facilities, etc. This could pave the way for cooperation between Europe and its neighbours for a multi-sectoral integrated policy (Ben Abdallah et al. 2013).

However, despite the huge Desertec initiative launched by the German enterprises in the framework of the Mediterranean Solar Plan promoted by the UfM and despite the enlargement of the trans-Mediterranean electricity grid, such a policy would have to be accompanied by strong commitments - on both the North and South sides - to come into force. For now, the Europeans cannot even manage to set up a European energy policy to better resist Russia's growing influence; they remain far from designing in common with their neighbours a Euro-Mediterranean energy policy. This section provides the main reasons why they should do so. Another shortcoming is that time is running short for the 
Table 1.7 Energy net trade: the complementary between Europe and its neighbours, 1990-2011

\begin{tabular}{lrr}
\hline & 1990 & 2011 \\
\hline European Union & -42 & -51 \\
Middle East and North Africa (developing only) & 206 & 79 \\
$\quad$ of which Algeria & 351 & 248 \\
of which Egypt & 70 & 14 \\
of which Libya & 555 & 132 \\
$\quad$ of which Syria & 113 & 18 \\
Iran & 171 & 67 \\
Iraq & 460 & 253 \\
Kuwait & 453 & 375 \\
Qatar & 324 & 535 \\
Saudi Arabia & 519 & 222 \\
Yemen Republic & 273 & 161 \\
Russian Federation & 47 & 80 \\
\hline
\end{tabular}

Note: Net energy imports = production less energy use (both measured in oil equivalents), as percentage of the energy use. A negative value indicates that the area is a net importer.

Source: International Energy Agency/World Bank Online.

Mediterranean neighbour countries that are energy producers: they are net exporters of energy but less and less so, because they are hardly modernising their energy production and/or because their own needs are rising; the trade power is bigger for the Gulf States and for Russia, but the partnership with them is much more complicated for Europe (Table 1.7). Indeed, the complementarity between a net importing Europe and net exporting Mediterranean neighbours is an asset, but it is a declining asset.

\subsubsection{Forecasting 2030: No Area in the World will Experience a Quicker Electricity Demand Growth than the South Mediterranean}

The OME 1 'Mediterranean Energy Perspectives' (MEP), published every three years, is an authoritative publication. It covers 24 countries of the Mediterranean rim, including European Mediterranean countries, Western Balkans, Turkey and the countries of the Mediterranean neighbourhood. A most interesting aspect is that it provides prospective scenarios to 2030. The shortcoming of this publication is that is does not give figures for all European countries. Nevertheless, it provides a useful prospect 
of European stakes throughout its Mediterranean countries (Portugal, Spain, France, Italy, Malta, Greece and Cyprus). The 2030 perspectives are analysed through two demand scenarios: a 'conservative scenario' (cs) pursues the actual trends, whereas a 'proactive scenario' (ps) is based on a slowdown of the rising energy demand, better energy efficiency and larger use of renewable energy (RE). Here are the main lessons learnt from this MEP (OME 2011).

The key information about the region's energy demand (here 'region' means the 24 countries of the Mediterranean rim) is its impressive rise: $+40 \%$ between 2010 and 2030, but only $+20 \%$ if robust policies are set up. The major fact is that, anyhow, $75 \%$ of the increase will come from the South. Figure 1.4 shows the impressive growth of energy use ${ }^{2}$ in the South Mediterranean countries. The proactive scenario would diminish this rise but not that much. In 2030, in any of the two considered

Energy use in the Mediterranean countries, 1990-2030

2030: according to two scenarios

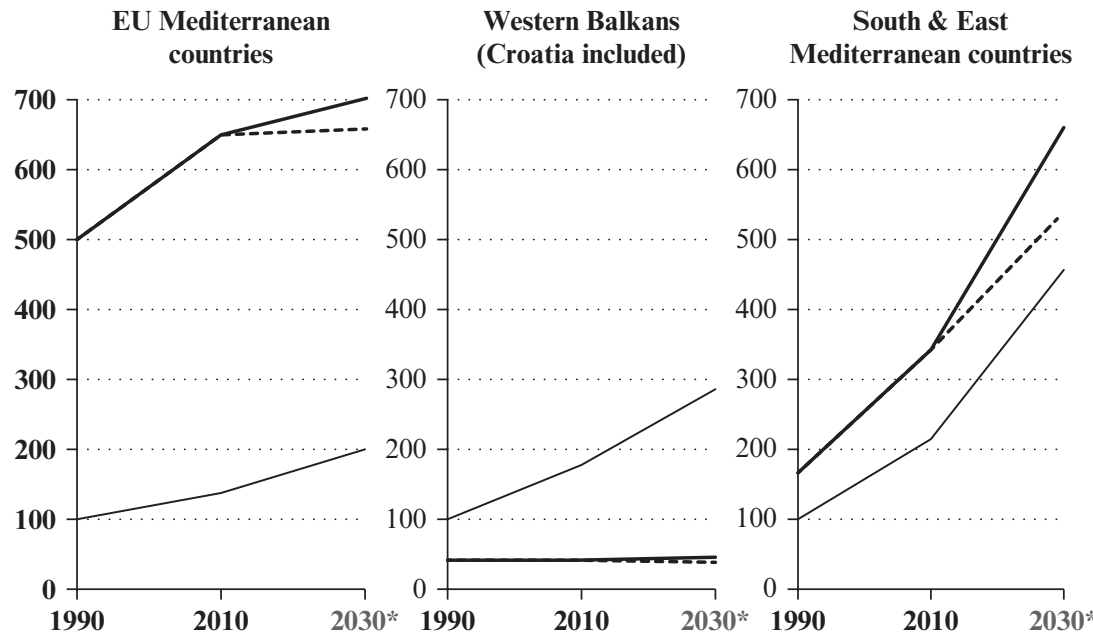

—- Energy demand (Mtoe) conservative scenario
- Energy demand (Mtoe) proactive scenario
GDP (billion 2005 US\$, PPP, year 1990=100)

ESP N $\odot$ CNRS GIS CIST, ITAN, 2013

Note: EU Mediterranean countries: Portugal, Spain, France, Greece, Malta, Cyprus. SEMCs: including Turkey and Israel.

Figure 1.4 Energy use in the Mediterranean area, 1990-2030, two scenarios 
scenarios, the energy use would be almost as high in the Southern Mediterranean countries as in the EU Mediterranean countries, whereas the Western Balkans would experience a stagnating energy use. Such an evolution should not be astonishing: a rise in energy use goes along with the development process.

This is bad news when it comes to the environment. Regional $\mathrm{CO}_{2}$ emissions would increase by $9 \%$ in the proactive scenario, and still more in the conservative scenario: $+40 \%$. $\mathrm{CO}_{2}$ emissions are much lower in the Southern neighbourhood than in Europe; unfortunately, Southern emissions will particularly increase. However, this is good news when it comes to potential markets for European companies. It has to be highlighted that the Mediterranean electricity demand and supply will be particularly booming. Up to 2030, no area in the world will experience a stronger electricity demand growth than the Southern Mediterranean countries, at an average rate of $5 \%$ per year. This trend has a major territorial aspect: electricity grids are to be major infrastructures for the coming years. This represents at the same time huge investments (including for European investors) and many territorial challenges; in particular, rural development will not be possible if these territories are not provided with an electricity supply. Between 2010 and 2030, electricity production will be multiplied by 1.4 in the EU Mediterranean countries (Map 1.12), and by 1.3 if they choose the proactive scenario; it will be multiplied by 2.6 in the South Mediterranean (by 2.1 in the proactive scenario). In other words, up to 2030, the developed electricity capacity in the Southern rim, including Turkey and Israel, could be almost as important as the existing capacity in the EU Mediterranean countries!

The second lesson is that general figures show a diminishing gap between the North and the South of the Mediterranean. The energy use per capita gap will decrease somewhat by 2030 . The figures are almost stagnating for EU Mediterranean countries, but they are booming in the south. This is particularly so for Israel (whose level of energy per capita should exceed that of EU countries by 2030) and Turkey, but even without these two countries, the South Mediterranean Arab countries will partly bridge the gap vis-à-vis the Northern side. In 1990, Arab Mediterranean countries' ratio of energy use per capita was a quarter of that of the EU Mediterranean countries; in 2030 it will be half. 


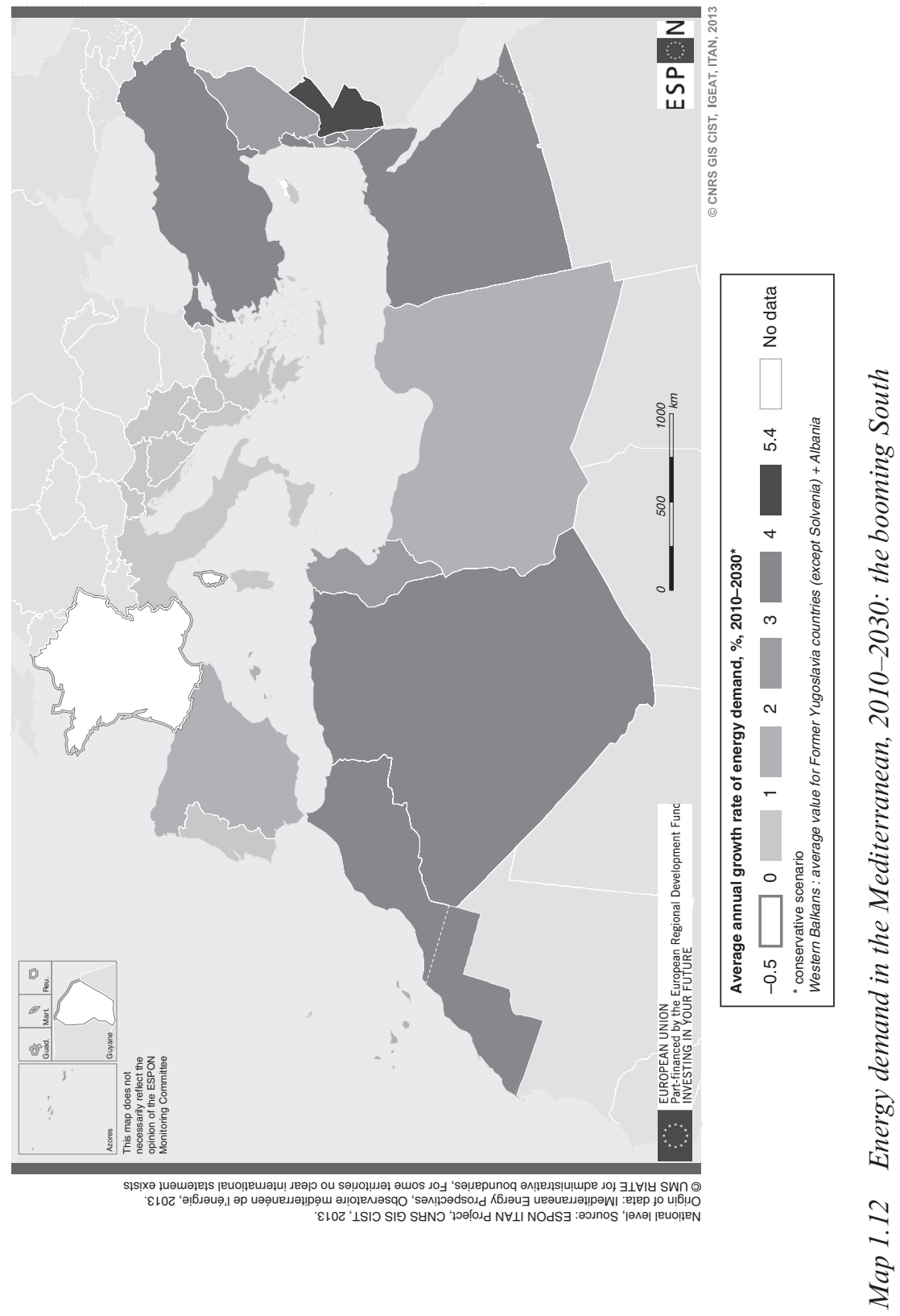



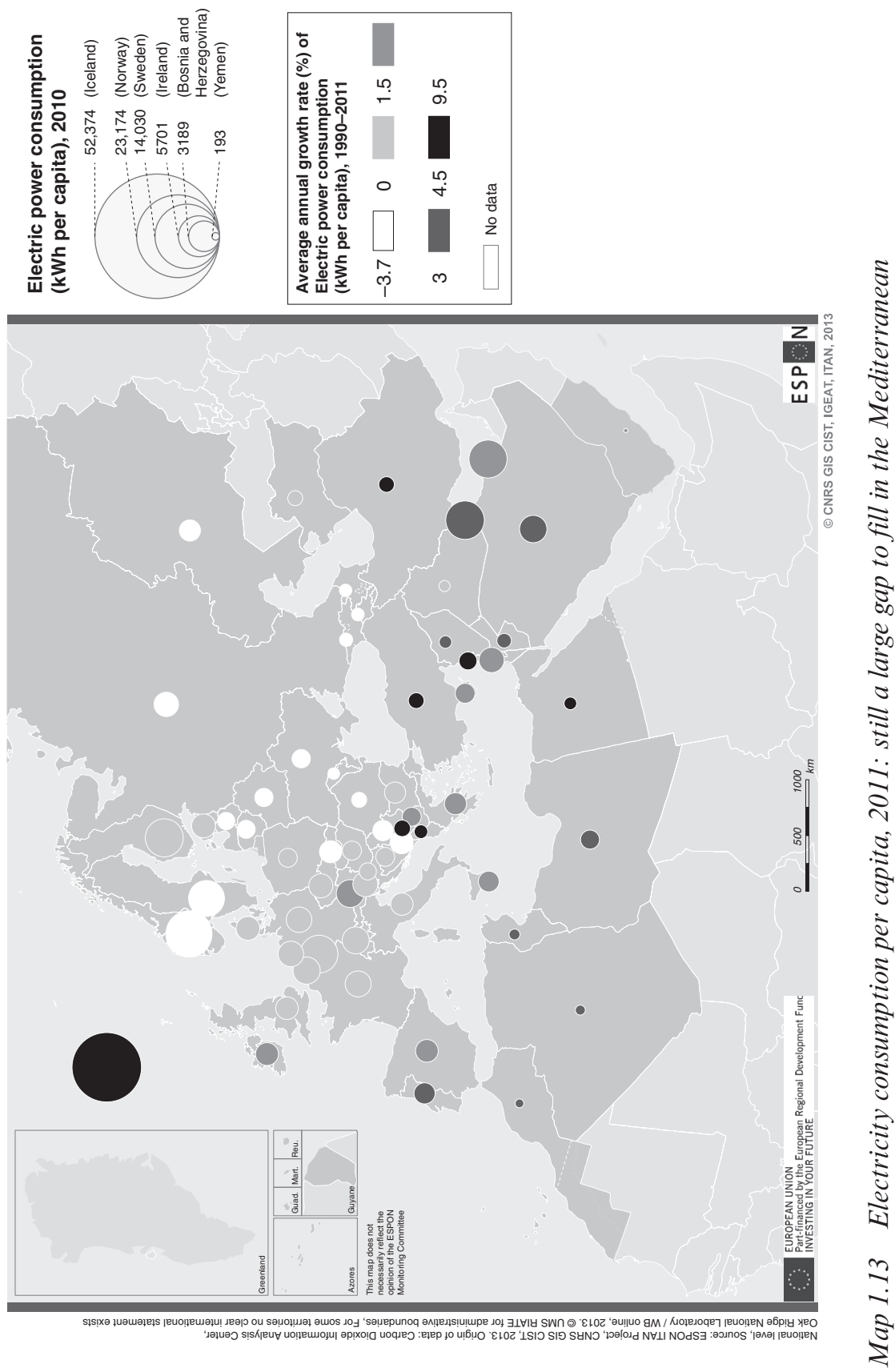


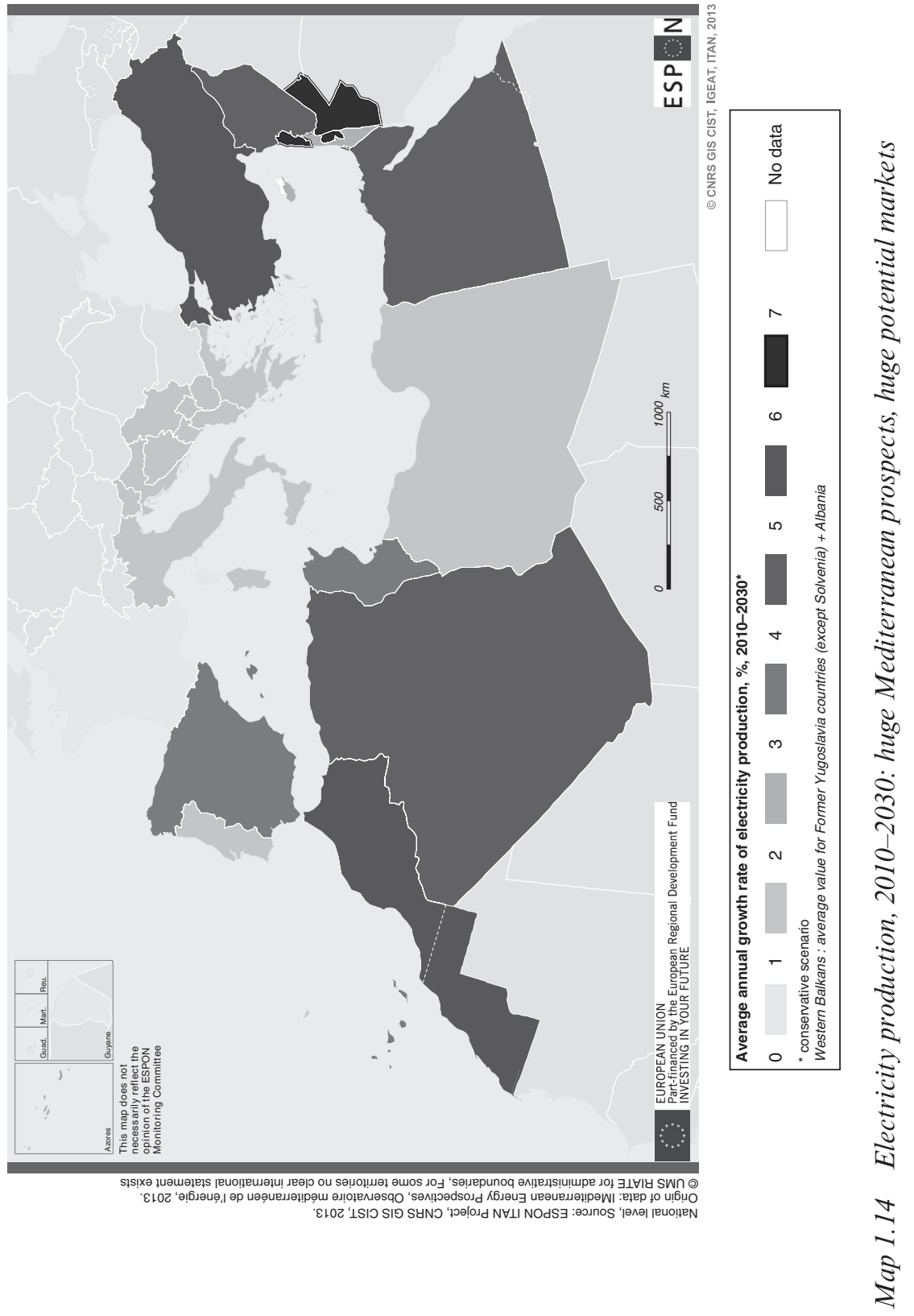




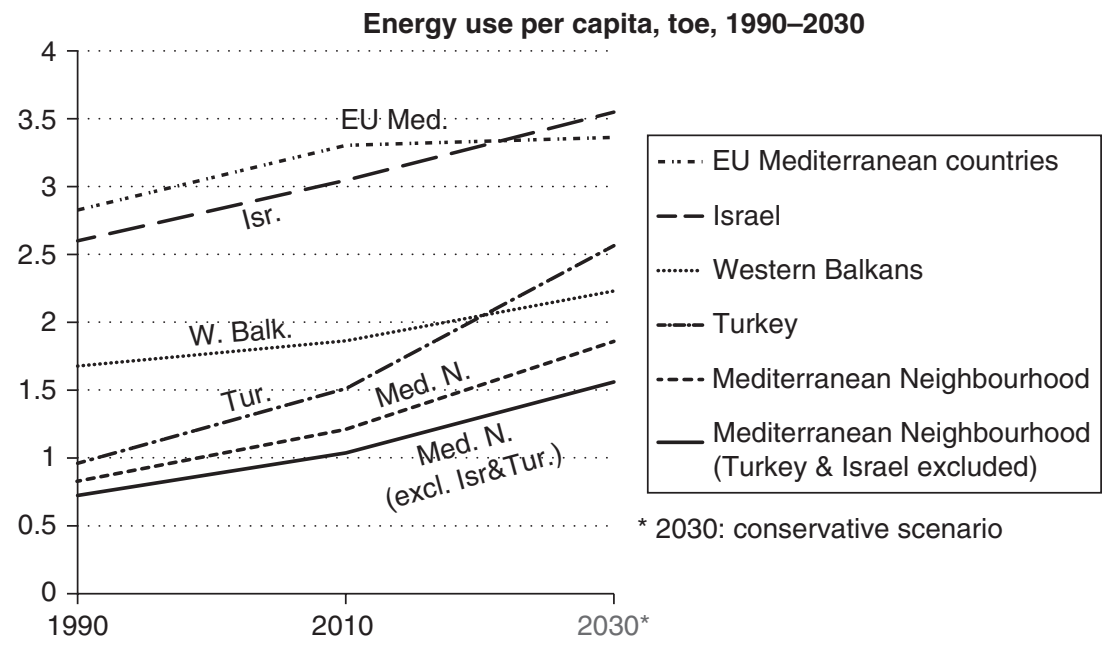

Note: EU Mediterranean countries: Portugal, Spain, France, Greece, Malta, Cyprus.

Source: OME.

Figure 1.5 Energy use per capita in the Mediterranean area: a convergence

\subsubsection{Energy Transition in the Mediterranean Neighbour Countries: a Remote Perspective}

The third lesson is that energy transition will not be an easy task in the region. Yet the difference between the conservative and the proactive scenarios is much bigger in the South than in the EU: in the South the energy use would be $18 \%$ smaller if the proactive scenario was implemented; in the EU Mediterranean countries the decrease would only be $6 \%$. Nevertheless, the transition of the South to better energy efficiency and to renewable fuels will require high levels of commitment.

Solar electricity production will develop on both sides of the Mediterranean. Today, it only really exists on the Northern side; in 2010 the solar production in the South was $1 \%$ of the EU Mediterranean production; in 2030 it could be $18 \%$ (cs) or 38\% (ps). However, even in the proactive scenario, the Southern production will stay far behind (see Table 1.8). The reasons for this are (a) the low capacity of these countries to subsidise their solar industry (this capacity has severely diminished in Europe since the financial crisis but remains much higher than in the South); (b) the lack of technology and industrial know-how; and (c) a 
Table 1.8 Solar electricity production (TWh) in Mediterranean countries, 2010-2030: the South lags behind

\begin{tabular}{lccc}
\hline & & Conservative Scenario (cs) & Proactive scenario (ps) \\
& 2010 & 2030 & 2030 \\
\hline Spain & 7.6 & 42.8 & 45.9 \\
Italy & 1.9 & 42.7 & 46.0 \\
France & 1.1 & 11.2 & 13.7 \\
Turkey & 0.0 & 8.8 & 17.5 \\
Algeria & 0.0 & 1.7 & 13.7 \\
Morocco & 0.0 & 4.1 & 5.7 \\
Israel & 0.0 & 1.6 & 2.6 \\
Jordan & 0.0 & 1.2 & 2.3 \\
Egypt & 0.1 & 0.6 & 1.2 \\
Tunisia & 0.0 & 0.2 & 0.6 \\
Libya & 0.0 & 0.0 & 0.5 \\
Syria & 0.0 & 0.1 & 0.3 \\
Palestine & 0.0 & 0.0 & 0.1 \\
Lebanon & 0.0 & 0.0 & 0.0 \\
\hline
\end{tabular}

Source: Mediterranean Energy Perspectives, OME.

lower sensitivity to this issue than in Europe. This is ironic, since the solar potential is indeed much higher in the South than in the North.

According to the European plan on climate change adopted by the European Parliament in December 2008 ('20-20-20 targets'), EU member states will have the possibility to include imported renewable energy among the $20 \%$ RE of their policy mix - namely imported from Saharan solar plants. In 2030 the MEP states in its proactive scenario that the two major solar players in the Mediterranean will be Spain and Italy (46 TWh); far behind could come Turkey (18), France and Algeria (13) if it manages to launch an industrial and technological initiative towards becoming a leading country in the energy field - but will it succeed without a strong trans-Mediterranean cooperation? Morocco (6 TWh) would come far behind, not to speak of Jordan (2.3) and Tunisia (0.6).

As a matter of fact, the Mediterranean energy mix will remain largely dominated by hydrocarbons in 2030, whatever the scenario, and especially in the South. Figure 1.6 shows this clearly: hydrocarbons, in particular natural gas, will be very prominent in the South Mediterranean mix. One explanation comes from hydrocarbons production figures: three countries - Libya, Algeria and Egypt - hold 94\% of Mediterranean oil reserves. Libya will continue to increase its levels of oil production to 2030; 


\section{Energy use by type of energy, \%, 2010-2030}

2010

EU Mediterranean countries
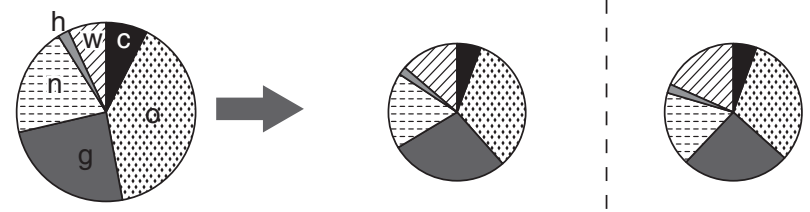

Western Balkans
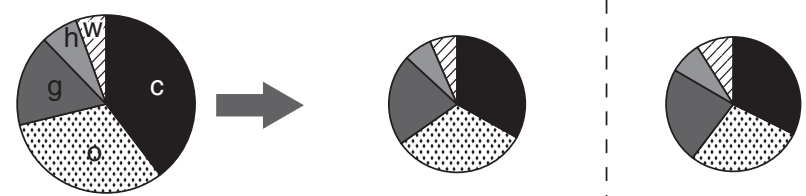

Southern \&
Eastern
Mediterranean
Countries
(Turkey \& Israel
excluded)
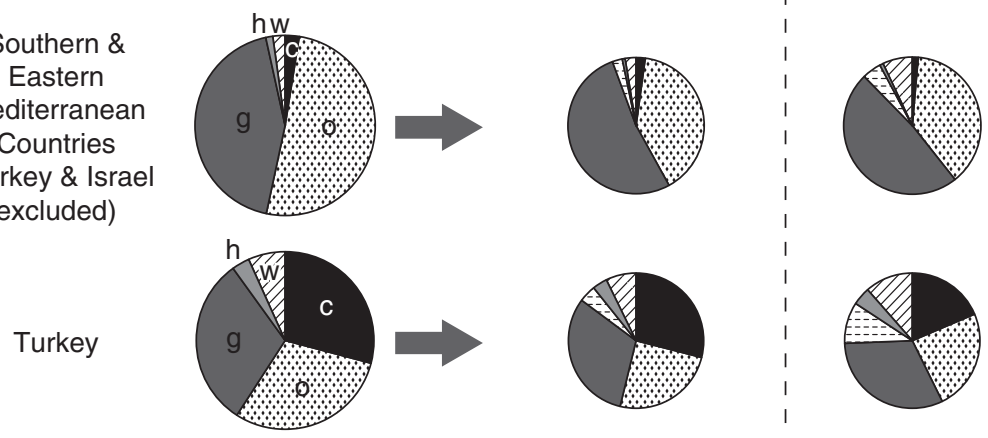

$$
\begin{aligned}
& \text { - Coal (c) 日 Nuclear (n) } \\
& \text { 园 Oil (o) } \quad \text { Hydro (h) } \\
& \square \text { Gas (g) } \square \text { Wind, solar, other } \\
& \text { renewables \& waste }(w)
\end{aligned}
$$

Note: EU Mediterranean countries: Portugal, Spain, France, Greece, Malta, Cyprus.

Source: OME.

Figure 1.6 Energy use by type of energy in the Mediterranean in 2030: two scenarios

total oil production in the Mediterranean will remain above $6 \mathrm{mb} / \mathrm{day}$ in 2030.

Over the next two decades, natural gas production is expected to double, especially in Algeria but also in the Eastern Mediterranean, where important reserves have been recently discovered in the 'Tamar' and 'Leviathan' 
fields, close to Egypt, Gaza strip, Lebanon, Israel and Cyprus. The latter two are on their way to becoming gas exporters in a decade. Gas will overtake oil as the dominant energy source over the period, especially in the South Mediterranean, owing to a strong demand coupled to attractive prices and easy availability. In a word, heavy reliance on fossil fuel will endure in the South. In the conservative scenario, the share of wind, solar and other renewable energy sources in the Arab Mediterranean countries (Israel and Turkey not included) will represent only $2.5 \%$ of the total energy use. As a whole, to 2030 the Mediterranean region will remain a net importer of oil and gas regardless of the scenario.

Figure 1.7 gives a synthetic picture of the conservative scenario: the rising share of hydrocarbons in all the parts of the Mediterranean region and most particularly in the South; the rising role of gas - hence the importance of gas pipes infrastructures and the long term contracts vs spot market issue in the gas sector - and a tiny share of renewables.

\subsubsection{Avenues for Cooperation with European Neighbour Countries: Energy Efficiency, Renewable, Key Role of Electricity Grids}

The fourth lesson is the importance of promoting energy transition in the region, especially in South Mediterranean countries. Current energy trends are not sustainable and would jeopardise energy security. In addition, in the conservative scenario the energy intensity, that is energy use out of GDP, will hardly decrease in the Mediterranean neighbourhood. The decrease will be impressive in the Western Balkans (in 1990 the energy intensity was extremely high), and it will significantly decrease in the EU Mediterranean countries. According to this indicator, the gap is rather enlarging between the North and the South.

Even if the Mediterranean region should dream of a very windy and sunshiny energy future, renewables could only supply $15 \%$ of primary energy demand by 2030 in the proactive scenario. Solar photovoltaics would then grow at a rate of $15.5 \%$ per year in the Mediterranean region and $39 \%$ in the South.

Along with that, the potential for energy efficiency is very important: $10 \%$ of the regional energy demand could be saved by 2030 . This is particularly so for South Mediterranean countries, if they choose a lighter model of development for energy use, but in that case adapted institutional and legal frameworks are needed. The Plan Bleu ${ }^{3}$ estimates that, for the two coming decades, investment needed in the Mediterranean neighbours to build energy-efficient buildings would amount to $€ 260$ billion. On the other hand, it would create 2 million jobs by 2030, including in the informal sector (Thibault and El Andaloussi 2011). On the Mediterranean regional 

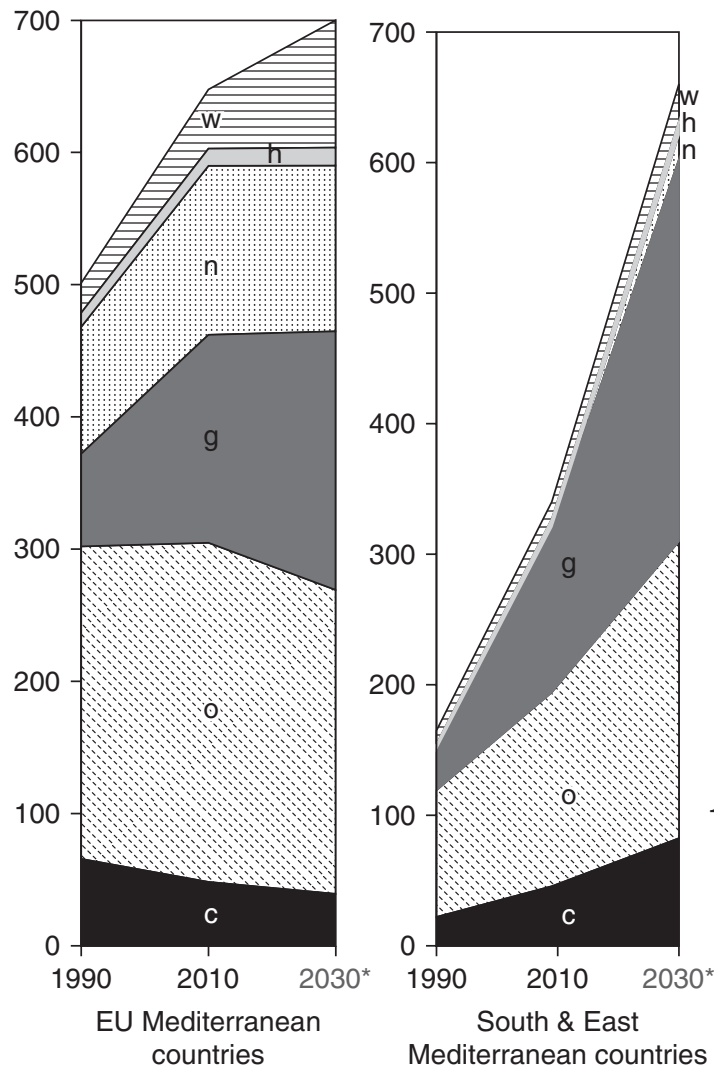

Energy use, 1990-2030

by type of energy (Mtoe)

- Coal (c)

因 Oil (o)

$\square$ Gas (g)

目 Nuclear (n)

$\square$ Hydro (h)

目 Wind, solar, other

renewables \& waste $(w)$

*2030: conservative scenario

Note: EU Mediterranean countries: Portugal, Spain, France, Greece, Malta, Cyprus.

Source: OME.

Figure 1.7 Energy use by type of energy in the Mediterranean area: a hydrocarbonic future

scale, oil and natural gas net import requirements would be nearly halved by 2030 in the proactive scenario, as compared with the conservative scenario. In the proactive scenario, the South as a whole would meet its electricity demand, thanks to less additional capacity needs, more renewable energy, more energy efficiency gains and substantial upgrade of networks.

The last lesson is the rising role of electricity grids in territorial development and cooperation in the Mediterranean neighbourhood. Here the OME statement is strategic: 'while oil and gas trade have brought about fruitful long-term Mediterranean partnerships for decades, nowadays 


\section{BOX 1.1 TOWARDS A COMMON NORTH-SOUTH MEDITERRANEAN SCHEME FOR ENERGY TRANSITION?}

\section{The Mediterranean Solar Plan}

According to Trans-Mediterranean Renewable Energy Cooperation (TREC), 0.3\% of the Saharan surface could provide all current and coming energy needs for Europe and its Mediterranean neighbours. The issue is to make this potential both actual and fair between Europe and its Mediterranean partner countries. Launched in 2008 as an emblematic project of the Union for the Mediterranean, the Mediterranean Solar Plan has as its main focus solar, but it also addresses wind and, on the side-lines, biomass. The aim is (a) to increase the proportion of renewable energy in the Southern countries' energy mix, and in Europe, and (b) to increase energy supply security in urban and rural areas in North and South alike.

The plan has two major themes. The first is the deployment in Mediterranean neighbour countries of a large number of solar energy production sites (photovoltaic cell clusters and concentration solar energy), with wind and biomass sites as a complement. Output was planned to reach $20 \mathrm{GW}$ by 2020 for a total investment of $€ 80$ billion, an amount of money that is difficult to raise. The second is the manufacture in the neighbour countries of solar panels, solar radiation concentrators and related equipment in order to contribute to their productive modernisation and to the rise of seawater desalination. In the longer-term perspective, meeting South-North electricity transport requirements stemming from the implementation of the Mediterranean Solar Plan will require the creation of around half a dozen new links (at a cost around $€ 800$ million per link).

\section{Desertec, a North-South win-win project?}

Desertec is a non-profit foundation funded in majority by German stakeholders. It aims to provide $15 \%$ of Europe's electricity by 2050 through a vast network of solar and wind farms stretching right across Mediterranean neighbour countries and connecting to continental Europe via special high-voltage, direct current transmission cables, which lose only around $3 \%$ of the electricity they carry per $1000 \mathrm{~km}$. The tentative total cost of building the project has been estimated at $€ 400$ billion.

This initiative has rapidly been criticized by the South because it was designed for Europe's profit. Since then, it has been rather the electricity distribution in Southern markets that has been emphasised. Recent debates add that a better electricity connection between the North and the South could, in a first step, rather drive to North-South exports thanks to Europe's nuclear plants, waiting until a second step when solar electricity has become profitable.

\section{Medring, achieving the Mediterranean electricity loop}

The development of renewable energies in the Mediterranean neighbourhood would benefit from another project related to the electric grid. Presently North African and Eastern Mediterranean countries have partially separated high-voltage networks working with non-synchronous frequencies. Thus there is no electricity transmission among these countries at a large scale. However, the European network of transmission system operators for electricity (ENTSO-E) is developing an ambitious plan to connect the different isolated networks, effectively creating a 
closed ring of electric networks around the Mediterranean, the so-called Medring. This future network would create a Mediterranean electricity loop. It would merge the electric distribution systems of Europe and the Mediterranean neighbourhood effectively, helping to achieve some of the priorities of the EU energy policy: security, adequacy, market and sustainability. In particular the sustainability criteria could be fulfilled when coupling the Medring distribution network and the Desertec generation plants.

electricity (through renewable) emerges as another strong driver for reinforcing regional cooperation'. This matters very much, because it makes electricity grids a major component of territorial development within the Mediterranean neighbourhood and through trans-Mediterranean connections.

\subsection{WATER AND AGRICULTURE ISSUES NEED A REGIONAL DEEP INTEGRATION}

According to the scenarios of the Intergovernmental Panel on Climate Change and along with north-western India, the impact of climate change in the coming century will nowhere be harder than in the Mediterranean. The water shortage will become more severe; the arid part of this territory could then increase and agricultural modernization could be insufficient for tackling the utmost dependence of these countries on food imports and the Mediterranean neighbour countries are already the major importers in the world for cereals. Water and agriculture can be the source of major instability in the region, or they could become the cornerstone of an in-depth cooperation between Europe and its neighbours.

\subsubsection{The On-going Exploitation of Water is not Sustainable}

South Mediterranean countries suffer from a structural water stress. North Africa only gathers $0.1 \%$ of the world's renewable natural water resources and the Middle East $1.1 \%$, for $4 \%$ of the world's population. The area hosts about $60 \%$ of the world's population at the 'scarcity' threshold - access to only $1000 \mathrm{~m}^{3}$ of water per inhabitant per year. In all, 45 million people in these countries do not have access to sanitation facilities, and 20 million to fresh water (Plan Bleu 2013). Access to improved plumbing systems (latrines, pour-flushed toilets, etc.) is especially insufficient in rural areas. In Morocco, $30 \%$ of the population have no access to improved wastewater infrastructure and $48 \%$ in rural areas (Orjebin-Yousfaoui 2014). In 
the Near East, $11 \%$ of deaths of children under 5 are due to diarrhoea linked to limited access to drinking water and sanitation issues. Between 1 and $5 \%$ of deaths in the area, regardless of age and sex, are due to insufficient or inadequate services in the field of water, hygiene and sanitation. In terms of marine environment, $70 \%$ of sewage water poured into the Mediterranean Sea every year is not treated. The issue is also geopolitical, particularly in the Near East and for the Nile Valley, since Mediterranean natural water resources are mostly trans-boundary.

The prospects are still more worrisome. Demographic growth will increase the pressure on water resources; water consumption will increase from 170 to $228 \mathrm{~km}^{3}$ by 2025 . The Plan Bleu assumes that, in 2025,250 million inhabitants of the Mediterranean neighbour countries could be in water 'poverty' and 80 million in a water 'scarcity' situation. The World Bank estimates that water availability per inhabitant in the area will decrease by half in 2050 compared with 2007.

Orjebin-Yousfaoui (2014) assumes that $\$ 10$ billion per year is needed in the South Mediterranean for the building of new infrastructures and networks extension (source: WHO, as referred to in the Millennium Development Goal strategy), excluding the cost of maintenance of the existing infrastructure and reinforcement of the institutional capacities. On the other hand, the economic actual cost of poor-quality water in Middle East and North African countries is estimated at between 0.5 and $2.5 \%$ of their GDP, according to the 4th UN World Water Development Report. Also, according to the UN 'Water Global Analysis and Assessment of Sanitation and Drinking-Water' report, better access to water and sanitation could increase GDP by $2 \%$ to $7 \%$. In other words, investments in the field would bring in 4-12 times more than they cost.

The Mediterranean Water Strategy of the Union for the Mediterranean says that 'by 2020, according to the capacities, the necessary investments will be made to ensure that $100 \%$ of the urban and rural population have access to quality water and sanitation services'. The trouble lies in 'according to the capacities'. Since 1976, Mediterranean water issues have been at the centre of numerous debates, and yet little progress has been made. What the region needs is real coordination, because the water and climate issue is not national, even though water can appear as a local resource. Proposals for a Euro-Mediterranean governance are on the table (Comair et al. 2010): a 'Euro-Mediterranean Water Council' could gather representatives of heads of state because water is far from being the only concern of ministries of water - it is also a matter of agriculture, in particular. It would also include representatives of the major towns in the region and directors of NGOs and institutions working with Mediterranean water. This Council would determine the strategy of a 'Mediterranean 
Water Agency', whose running and executive decisions could be entrusted to professionals representing basins or other relevant areas - and not the public water administration alone - covering all actions necessary for integrated water and sanitation management. The Agency's charter would echo the common principles about pricing and clear contracts which would need to be respected to receive funding from public and private international donors. Its missions would be information, promotion of new water practices for agriculture (which uses three-quarters of the region's water), exchange of experience, vocational training, research and hydro-diplomacy, that is mediation on trans-boundary waters. Beckouche, Besnard and Pecout (2016) say that this is realistic: the Mediterranean neighbours are already adapting their regulation to make it closer to the EU Water Framework Directive. They set up water supply basin agencies according to European patterns. They acknowledge that they need European know-how. Conversely, European stakeholders acknowledge that there are business opportunities in the Mediterranean and that good local governance of water management is an excellent way to promote citizens' participation, and to avoid possible water wars.

\subsubsection{The Mediterranean Neighbour Countries are Among the Major Food Importers in the World}

In the South Mediterranean, food insecurity is increasingly prevalent with a high risk of worsening in the coming decades (Abis and Blanc 2010). Even in countries such as Algeria, this is a key issue because the country, thanks to its recent Politique de Renouveau Agricole et Rural, wants to reduce its dependence upon food imports and to enhance its agricultural sector, which was left behind in the first decades of the republic.

We next sum up the main results of an authoritative work (Rastoin and Cheriet 2010). As the authors state, the Mediterranean neighbour countries, which used to be referred to as a bread basket for ancient Rome, have become over the centuries the most food-underserved area in the world. The gap between food local production and consumption reached 55\% in the 2000s; it could more than double by 2050, with a deficit three times higher than in Sub-Saharan Africa, long considered the most vulnerable region in the world.

Mediterranean food insecurity has five dimensions. The first is social, with half of the population still living in rural areas and $10-30 \%$ of the rural population below the poverty threshold, compared with $2-10 \%$ of the urban population. The rural poverty is not to be solved by urban growth and the internal migration from rural to urban space, because in the coming decades rural density will hardly diminish. 
The second dimension relates to public health, with inadequate levels of traceability and monitoring of the hygienic quality of food.

The third dimension is technical, regarding the difficulty of increasing local agricultural and food production. Over $80 \%$ of farms are less than 10 hectares, the average size of farms being ten times smaller in Egypt, where rural density is a major worry. These economies are suffering from the inadequacy of local raw materials, the lack of technological and managerial resources, the lack of coordination between agents and the shortcomings of the food security regulation (quality standards, product control and traceability).

The fourth dimension is environmental, with the depletion of natural resources that has been happening for half a century and climate change in the longer term.

The fifth dimension is macroeconomic, with a huge foreign trade deficit that has been widening over the past decades. Food products that weigh heaviest in the deficit are cereals (about $40 \%$ of the total food deficit), dairy products, animal feed, oils, oilseeds and sugar. With $4 \%$ of world population, this region accounts for more than $12 \%$ of cereal global trade. A first concern is about prices. In a context of probably highly volatile and rising international prices in the coming years, the impact will be all the harder on the national markets as protection schemes are being dismantled. With the slowdown of public subsidies, domestic prices will boom. Another macroeconomic consequence is about the financial amount of the trade deficit. In the mid-2000s, the deficit of the agricultural trade balance of the South Mediterranean was over $\$ 14$ billion (if we take Turkey out of the equation, the only country with surplus in the area), and it has widened since then.

Figure 1.8 gives the numbers for cereals production and imports in 2030 according to four scenarios. The first scenario is the baseline; it leads to a production per inhabitant of $80 \%$ compared with the $2000 \mathrm{~s}$, and to almost doubled imports. The second (severe climate change scenario) and the third (food trade total liberalization) lead to imports being multiplied by three. The combination of severe climate change and straight liberalization would lead to mushrooming imports (scenario $2+3$ ). The only scenario where production per inhabitant does not diminish and where imports remain bearable is that of a deep Euro-Mediterranean cooperation. It is easy to understand that the relevant strategy for Europe should not be limited to exporting its food surplus to its neighbours.

The problem is that, in the Mediterranean, international cooperation has hitherto proven to be a failure. If the Euro-Mediterranean is to become one of the geostrategic regions in the world, it has to take advantage of proximity, complementarity and solidarity to set up common food 


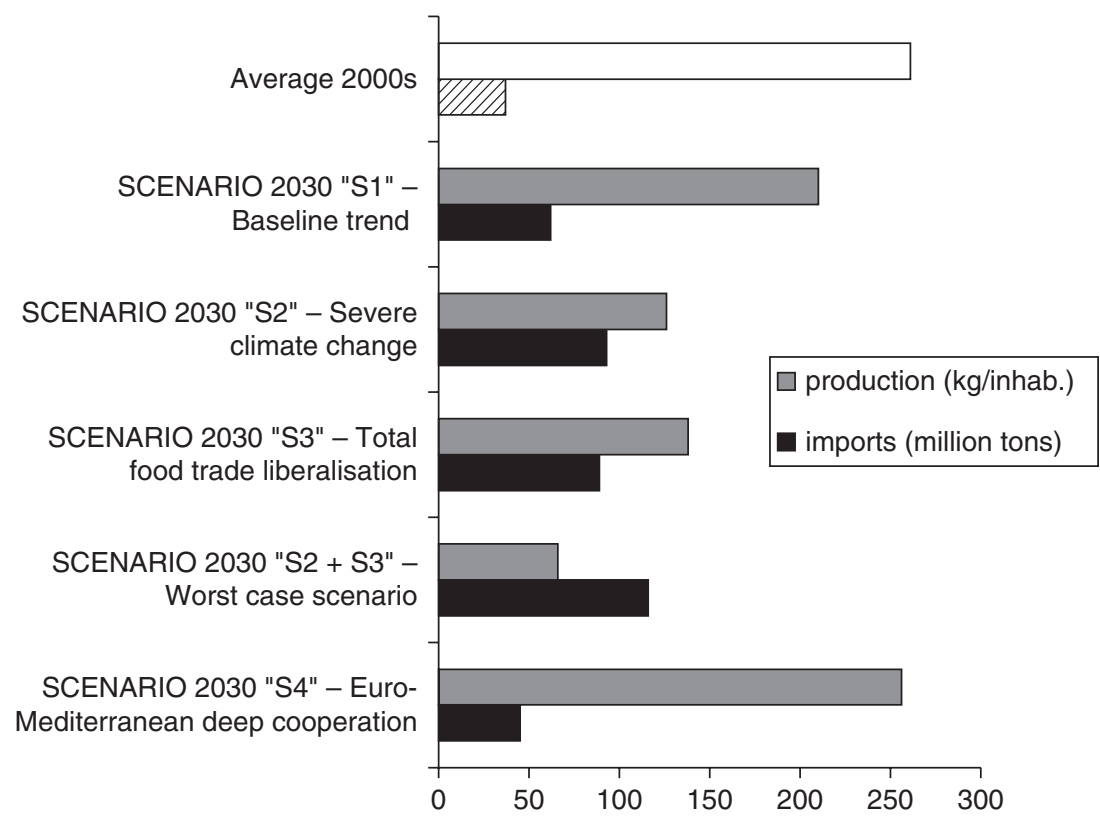

Note: Imports estimated as the difference between consumption and production. We take into account the average consumption per inhabitant of the 2000-2007 period.

Source: Inra-Cirad (2009)/Cheriet, Mohaved and Rastoin (2010), Institut de prospective économique du monde méditerranéen.

Figure 1.8 Cereals production and imports in the Mediterranean neighbour countries (except Turkey) in 2030

security. Several strategic directions can be considered by the two sides of the Mediterranean, Rastoin and Cheriet (2010) say.

When it comes to the food consumption model, stakeholders should promote the diet that prevailed half a century ago in the Mediterranean and which has now almost disappeared with the generalization of the Western food model. This requires national and Euro-Mediterranean policies based on informing and educating consumers, farms, food and distribution companies, and tourism actors. The Mediterranean diet, based on fruits, vegetables, olive oil and fish, is considered a 'nutritional standard', and is a much better option than supplements or medicalisation of food recommended by multinational companies.

When it comes to the supply side, the European know-how stemming from the Common Agricultural Policy (CAP) could be of great help, regarding $\mathrm{R} \& \mathrm{D}$, training, investment support, management of natural 
resources (land and water), guarantee of prices and markets, and structuring of the food sectors. The Common Market Organizations scheme, a key element of the CAP, enabled rapid modernisation of European production, benefiting both farmers and agribusiness clients. According to Rastoin and Cheriet, it would be highly desirable to adapt these mechanisms to the neighbour countries. Another extension of CAP know-how is about Geographic Labels (the kind of thing the USA wants to avoid in the possible future Transatlantic Trade and Investment Partnership): a common North-South promotion of Mediterranean Geographic Labels could help resist sharp competition from Californian, Chilean or Australian products, and conquer world markets.

When it comes to the trade side, what is striking is that, despite proximity and complementarity, a small share of the European farmers' exports goes to the Mediterranean neighbours, and that a limited share of these neighbours' imports comes from the EU (31\%, to be compared with $16 \%$ from the NAFTA and 15\% from the Mercosur (Mercado común del Sur) a rising share). A positive thing is that the EU Mediterranean countries import more South Mediterranean products than the other EU member states; in particular, this applies to fruits and vegetables, with dense cross-trading, which suggests complementarity rather than competition between the two Mediterranean rims. Euro-Mediterranean food security could consist of common strategic food stocks and a regional preferential food trade agreement so as to better ensure markets, deliveries and prices. Needless to say, such an option would imply tough disputes with the World Trade Organization.

This should come along with a stronger North-South inter-companies partnership. Except in Turkey and Israel, foreign investment is low in the South Mediterranean agricultures, according to Anima. ${ }^{4}$ Global firms (Nestlé, Danone, Coca-Cola, etc.) are already present in the Southern markets. They contribute to bringing technological and managerial skills to local actors, but their business model is heavily dependent on foreign shareholders' logic, whereas the Euro-Mediterranean partnership should encourage strategic alliances between small and medium-sized enterprises according to a co-development business model, both territory-oriented and non-hegemonic. Rastoin and Cheriet say that several food channels dairy products, oils and oilseeds, poultry meat and cereal by-products show many firm partnerships opportunities, and benefit from a large number of European companies in these activities. 


\section{NOTES}

1. The Observatoire méditerranéen de l'énergie (http://www.ome.org) is the reference EuroMediterranean body dedicated to energy issues: general analysis, specific studies on energy fuels, country profiles and perspectives.

2. That is the total energy use, whereas the 'energy final consumption' would not take into account the energy used to generate energy fuel available for households and companies.

3. As an UNEP body, the Plan Bleu (http://planbleu.org/) is the reference institution dedicated to environmental matters in the Mediterranean.

4. Anima Investment Network (http://www.animaweb.org/) is the authoritative body dedicated to the Mediterranean FDI data and study. It gathers national and regional investment promotion agencies, international organizations and business federations. 